\title{
THE EVOLUTION OF THE SIBERIAN CRATON, PETROGENESIS AND DIAMOND POTENTIAL OF THE MANTLE MAGMATIC SYSTEMS
}

\author{
P. I. Dorogokupets, K. N. Egorov \\ Institute of the Earth's Crust SB RAS, Irkutsk, Russia
}

Abstract: The article reviews the history, main scientific fields and major results of the studies performed by the Laboratory of Petrology, Geochemistry and Ore Genesis and the Laboratory of Geology and Magmatism of Ancient Platforms.

Key words: craton, mantle, diamond, kimberlite, basic rock, thermodynamics.

Citation: Dorogokupets P.I., Egorov K.N. 2014. The evolution of the Siberian craton, petrogenesis and diamond potential of the mantle magmatic systems. Geodynamics \& Tectonophysics 5 (1), 19-39. doi:10.5800/GT-20145-1-0116.

\section{ЭВОЛЮЦИЯ СИБИРСКОГО КРАТОНА, ПЕТРОГЕНЕЗИС И АЛМАЗОНОСНОСТЬ МАНТИЙНЫХ МАГМАТИЧЕСКИХ СИСТЕМ}

\author{
П. И. Дорогокупец, К. Н. Егоров \\ Институт земной коры СО РАН, Иркутск, Россия
}

Аннотация: Рассмотрена история, основные научные направления и основные научные результаты исследований за период 2009-2013 гг. в лаборатории петрологии, геохимии и рудогенеза и лаборатории геологии и магматизма древних платформ.

Ключевые слова: кратон, мантия, алмаз, кимберлит, базит, термодинамика.

\section{1. ВВЕДЕНИЕ}

Изучением эволюции Сибирского кратона, в том числе условий образования, петрогенезиса, флюидного режима и алмазоносности мантийных магматических систем, в ИЗК СО РАН занимаются две специализированные лаборатории - лаборатория петрологии, геохимии и рудогенеза (ЛПГР) и лаборатория геологии и магматизма древних платформ (ЛГМДП) под научным руководством академика Ф.А. Летникова.

Научное сотрудничество лабораторий осуществляется в проекте НИР «Эволюция Сибирского кратона; условия образования, петрогенезис, флюидный режим и алмазоносность мантийных магматических систем», финансируемом из госбюджета. Эти исследования отвечают Приоритетному направлению развития фунда- 
ментальной науки в РФ № VIII.72 «Рудообразующие процессы, их эволюция в истории Земли, металлогенические эпохи и провинции и их связь с развитием литосферы. Условия образования и закономерности размещения полезных ископаемых».

\section{2. ЛАБОРАТОРИЯ ПЕТРОЛОГИИ, ГЕОХИМИИ И РУДОГЕНЕЗА}

Лаборатория была организована Ф.А. Летниковым в 1965 г. на базе лаборатории экспериментальной петрографии и минералогии. С 2006 г. лабораторию возглавляет д.г-м.н. П.И. Дорогокупец. К наиболее значимым достижениям лаборатории во второй половине $\mathrm{XX}$ в. относится уникальный банк газовых хроматографических анализов горных пород в возрастном интервале от кайнозоя до раннего архея. Опубликовано 17 монографий по флюидному режиму в литосфере. Опубликована монография «Термодинамика минералов и минеральных равновесий». Академиком Ф.А. Летниковым опубликована монография «Синергетика геологических процессов».

\section{1. ИСТОРИЧЕСКАЯ СПРАВКА}

В настоящее время (начало 2014 г.) в лаборатории петрологии, геохимии и рудогенеза работает 15 сотрудников, в том числе академик РАН (рис. 1), 1 доктор и 8 кандидатов наук (рис. 2).

\section{2. ОСНОВНЫЕ НАУЧНЫЕ НАПРАВЛЕНИЯ}

В ЛПГР проводятся комплексные исследования эндогенных флюидных систем и их влияния на процессы минералообразования, выплавления магм, перенос и концентрирование рудных элементов, формирование рудных и нерудных месторождений в пределах Сибирской платформы и ее складчатого обрамления. Комплексность этих исследований заключается в следующем:

1) использовании современных аналитических методов (газовая хроматография, рамановская спектроскопия, электронная микроскопия, рентгенофазовый анализ, термический анализ, атомно-силовая и сканирующая электронная микроскопия и другие методы анализа),

2) экспериментальном исследовании флюидизированных силикатных и рудных систем при высоких давлениях и температурах,

3) численном физико-химическом моделировании флюидных систем и минеральных парагенезисов на основе специально разработанной термодинамики высокобарных минералов,

4) разработке уравнений состояния веществ и минералов для термодинамических условий, соответствующих мантии Земли.

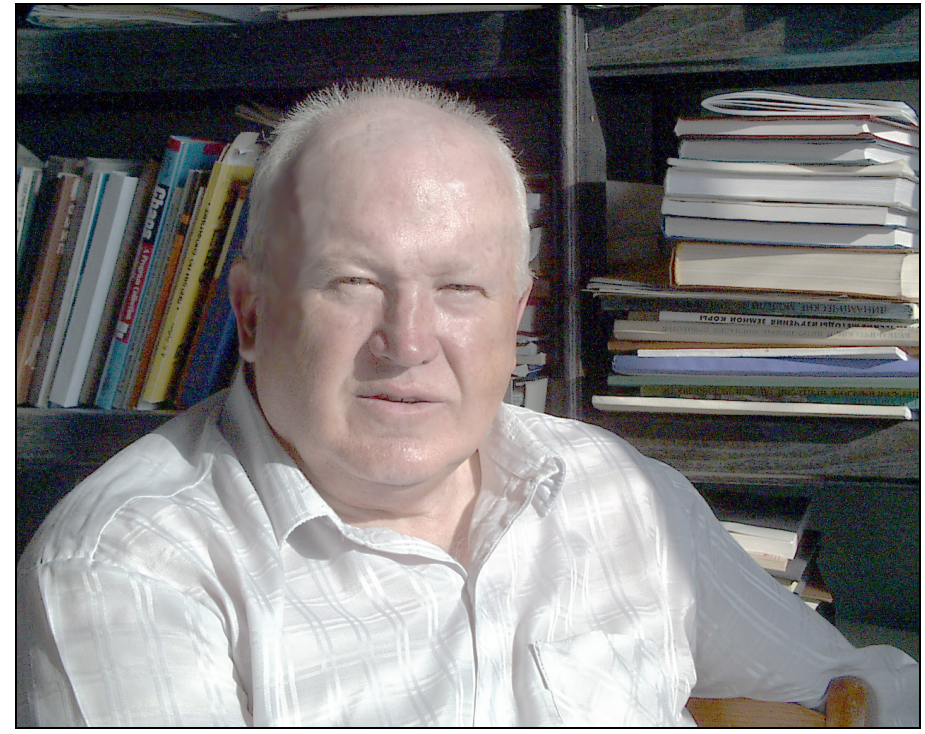

Рис. 1. Академик Ф.А. Летников.

Fig. 1. Academician F.A. Letnikov.

В течение последних пяти лет основным направлением исследований ЛПГР было изучение роли глубинных флюидных систем в формировании внутриплитных магматических комплексов; метасоматитов и метаморфитов во внутриразломных структурно-вещественных комплексах; условий образования, петрогенезиса, флюидного режима и алмазоносности мантийных магматических систем.

\section{3. ОСНОВНЫЕ НАУЧНЫЕ ДОСТИЖЕНИЯ}

На основании изучения эндогенных флюидных систем, проявленных в зонах глубинных разломов, сделан вывод о флюидной гетерогенности подстилающего астеносферного слоя и наличии здесь автономных флюидных систем. В одних случаях это восстановленные высокоуглеродные флюиды, в других - щелочные высокофтористые или бороносные системы с высоким содержанием редких и радиоактивных элементов. Проявление автономных флюидных систем наиболее характерно для докембрийских средних массивов, границ древних платформ и складчатого обрамления, заложенного на докембрийском основании. Проведено сопоставление 22 редких и рассеянных элементов из карбонатитов Дубравского массива ультраосновных щелочных пород и из графит-алмазных концентратов месторождения Кумды-Куль (Кокчетавская глыба, Северный Казахстан). Оба эти объекта приурочены к Чаглинскому глубинному разлому и сформировались в близком временном интервале. Полученные геохимические данные подчеркивают генетическое родство этих двух глубинных высокоуглеродистых флюидных систем: окисленной (карбонатиты) и восстановленной (графит-алмазная минерализация во внутриразломном 


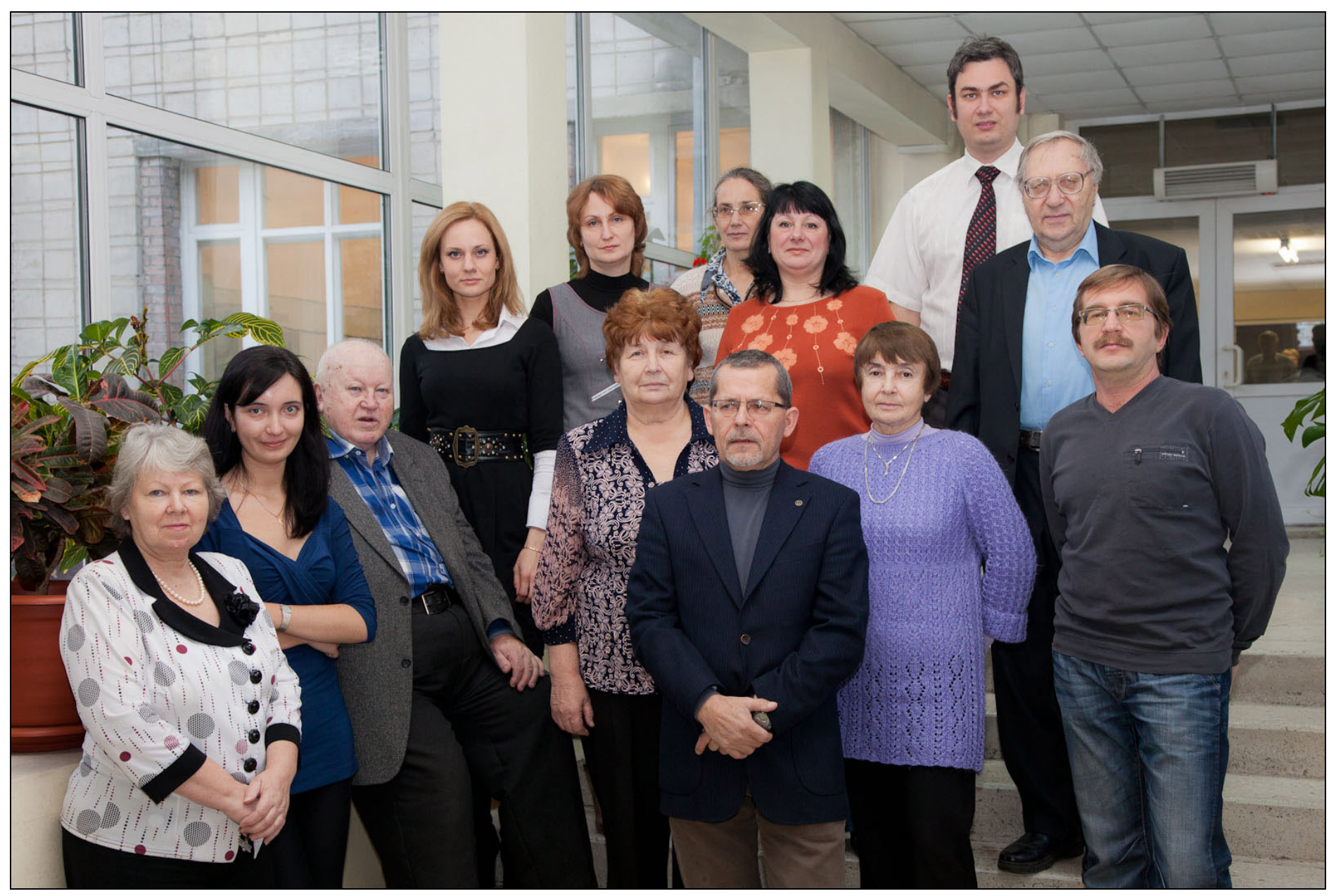

Рис. 2. Сотрудники лаборатории петрологии, геохимии и рудогенеза (слева направо): Н.В. Сизых, Т.С. Соколова, академик Ф.А. Летников, к.г-м.н. М.В. Марчук, к.г-м.н. Ю.Б. Данилова, Л.В. Баранова, к.г-м.н В.Б. Савельева, д.г-м.н. П.И. Дорогокупец - зав. лабораторией, Л.И. Меньшагина, к.г-м.н. Л.А. Иванова, А.В. Левин, к.г-м.н. В.Я. Медведев, к.г-м.н. Б.С. Данилов.

Fig. 2. The staff of the Laboratory of Petrology, Geochemistry and Ore Genesis (left to right): N.V. Sizykh, T.S. Sokolova, F.A. Letnikov, M.V. Marchuk, Yu.B. Danilova, L.V. Baranova, V.B. Savelieva, P.I. Dorogokupets (Head of the Laboratory), L.I. Men’shagina, L.A. Ivanova, A.V. Levin, V.Ya. Medvedev, B.S. Danilov.

пространстве) [Letnikov, 2009; Letnikov et al., 2010].

Проведена количественная оценка термодинамических параметров главных компонентов мантийного флюида до глубины 1000 км. Рассчитано приращение энтальпии (теплосодержания) газов при их подъеме с глубины 1000 км в верхнюю мантию и земную кору. Наибольшей энергетической емкостью по сравнению с другими газами обладает водород, что и обусловливает высокую степень энергетического воздействия на породы и флюиды собственно водородных систем [Letnikov et al., 2011, 2013].

В Северном Казахстане (Кокчетавская глыба) выявлены гранитные магматические системы, сформировавшиеся в одних случаях в результате воздействия на алюмосиликатную породную матрицу высокофтористых (топазовые граниты и онгониты), а в другом случае высокоборных (эльваны) флюидных систем. Взаимоотношения топазовых гранитов с ранее образован- ными жильными и дайковыми телами в массиве Тотогуз (Северный Казахстан) показывают, что процесс внедрения гранитоидной магмы, из которой затем образовались топазовые граниты, был несколько оторван во времени от послемагматического этапа становления гранитов третьей фазы [Levin, Letnikov, 2010; Turkina et al., 2011; Letnikov, Levin, 2013].

Изучение гранитов приморского комплекса $\mathrm{PR}_{1}$ в Западном Прибайкалье показало, что их формирование связано с глубокой дифференциацией больших объемов известково-щелочных магм, что обусловило кристаллизацию на заключительных этапах лейкогранитов, обогащенных летучими и гранитофильными редкими элементами, перспективных в отношении обнаружения оловянного оруденения грейзенового типа. На основании U-Pb датирования (SHRIMP-II) показано, что в Хамар-Дабанском и Бельско-Китойском террейнах Центрально-Азиатского подвижного пояса на 


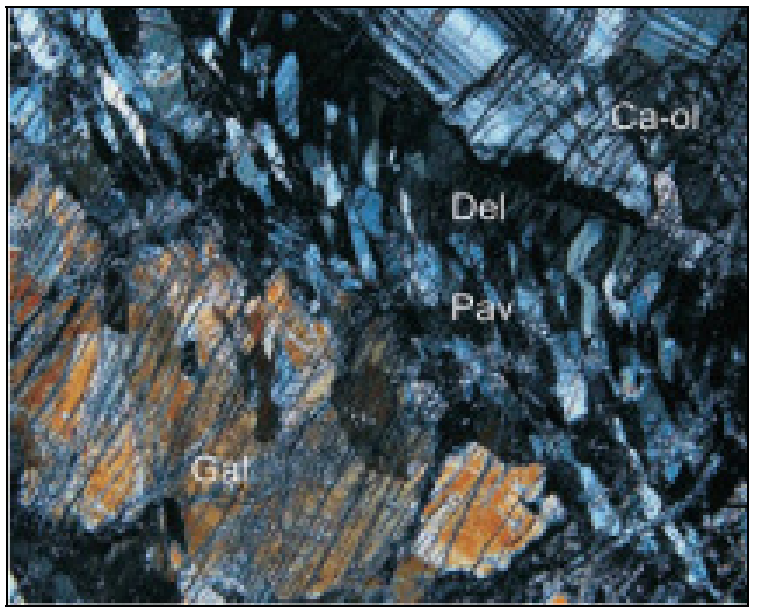

Рис. 3. Галускинит (Gal) и срастания павловскиита (Pav) с деллаитом (Del) в кальциооливиновом (Ca-ol) скарне Бирхинского массива.

Fig. 3. Galuskinit (Gal) and concretions of pavlovskiite (Pav) and dellaite (Del) in the calcium-olivine (Ca-Ol) scarn of the Birkhinsky massif.

границе с Сибирским кратоном наряду с позднеордовикской эпохой гранитоидного магматизма проявилась каменноугольная эпоха гранито- и пегматитообразования, отражающая тектоно - магматическую активизацию Главного Саянского разлома. Изучение щелочных метасоматитов Главного Саянского разлома позволило охарактеризовать данные метасоматиты как потенциально перспективные на обнаружение $\mathrm{Nb}-\mathrm{Zr}-\mathrm{TR}(+\mathrm{Th}$, $\mathrm{U}, \mathrm{Be})$ оруденения. Изучение геохимии и минералогии гранитов и пегматитов аинского комплекса в пределах Ольхонского террейна $\mathrm{Pz}_{1}$ позволило выделить новый для Прибайкалья тип пегматитов фтор-тантал-иттриевого минерагенического ряда с комплексной (Y-NbTa-W-Cs-Sn) минерализацией. В Западном Прибайкалье в скарнах на контакте с габброидами Бирхинского массива открыты новые минералы - павловскиит $\mathrm{Ca}_{8}\left(\mathrm{SiO}_{4}\right)_{2}\left(\mathrm{Si}_{3} \mathrm{O}_{10}\right)$ и галускинит $\mathrm{Ca}_{7}\left(\mathrm{SiO}_{4}\right)_{3}\left(\mathrm{CO}_{3}\right)$ (рис. 3) [Savel'eva, Karmanov, 2010; Savel'eva, Bazarova, 2012; Savel'eva et al., 2011, 2012; Armbruster et al., 2011; Lacis et al., 2011; Galuskin et al., 2012; Gfelleer et al., 2013].

Впервые выполнено описание графитсодержащих травертинов, ассоциирующих с гейзеритами и образующих самостоятельные жилы среди отложений ольхонской серии (Западное Прибайкалье). Для графитов из гейзеритов Прибайкалья установлена новая, ранее неизвестная в природных образцах, модификация углерода - $\alpha$-карбин, который находится в парагенетической ассоциации с графитом и битумоидами. Изучен состав и строение углеродного вещества метасоматитов Тункинского разлома (юго-восточная часть Восточного Саяна). Установлено, что в составе УВ присутствуют битумоиды - РУВ. РУВ углеродсодер-
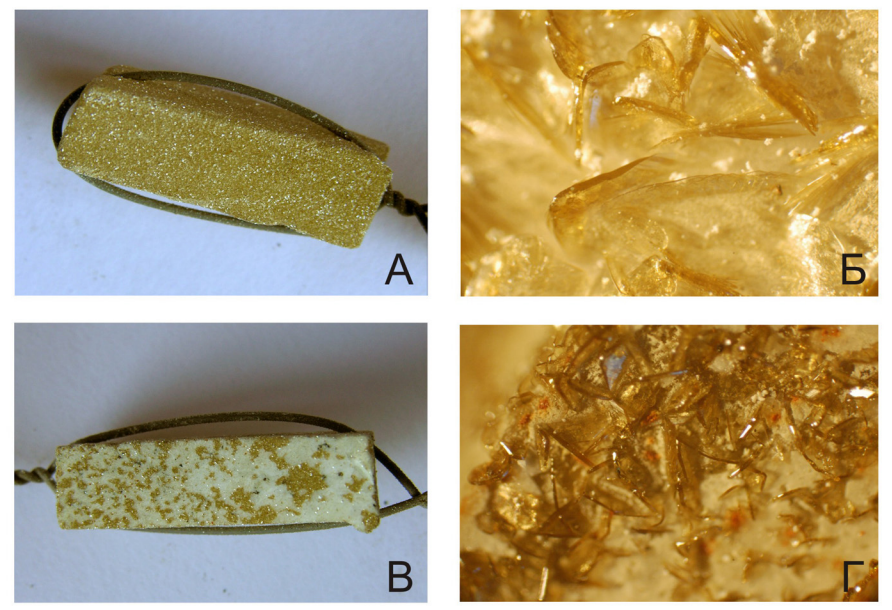

Рис. 4. Кристаллы фаялита на поверхности кварца $(A, Б)$ и кварцевых выделений в лейкократовом граните $(B, \Gamma)$.

Fig. 4. Fayalite crystals on the surface of quartz $(A, D)$ and quarts emissions in leucocratic granite $(B, \Gamma)$.

жащих пород Тункинского разлома представлен в основном линейными углеводородами [Shumilova, Danilova, 2009; Shumilova et al., 2011; Danilova et al., 2012].

Экспериментально показано, что при температуре $500{ }^{\circ} \mathrm{C}$ и давлении 1000 атм основным фактором, влияющим на образование различных модификаций медистого золота в системе $\mathrm{H}_{2} \mathrm{O}-\mathrm{NH}_{3}$, является количество вводимой в систему воды: до $10 \%$ - образуются кубические фазы; до 50 \% - тетрагональные. Установлено, что Si и Fe переносятся восстановленным флюидом в термоградиентных системах в присутствии $\mathrm{NaCl}$ как в гидротермальных, так и в безводных условиях с образованием фаялита на кварце и железосодержащих держателях. Форма огранки новообразованного фаялита зависит от состава субстрата, по которому он развивается (рис. 4, 5). Экспериментально показано влияние режима декомпрессии на перераспределение рудных и петрогенных элементов при самоорганизации гранитного расплава. Открыт новый минерал - владимиривановит [Marchuk et al., 2009; Ivanova et al., 2010; Letnikov et al., 2012; Sapozhnikov et al., 2012].

На основе одновременной оптимизации данных ударных экспериментов, ультразвуковых, рентгеновских, дилатометрических и термохимических измерений в диапазоне температур от $\sim 100 \mathrm{~K}$ до температуры плавления и до давлений в несколько мегабар с использованием модифицированного формализма построены уравнения состояния алмаза, $\mathrm{MgO}, \mathrm{Ag}, \mathrm{Al}, \mathrm{Au}$, $\mathrm{Cu}, \mathrm{Mo}, \mathrm{Nb}, \mathrm{Pt}, \mathrm{Ta}, \mathrm{W}$. Уточнена калибровка рубиновой шкалы давлений $\left[\mathrm{P}(\Gamma П а)=1870 \cdot \Delta \lambda / \lambda_{0}\left(1+6 \cdot \Delta \lambda / \lambda_{0}\right)\right]$ (рис. 6). Новые одновременные измерения объема $\mathrm{Au}$, $\mathrm{Pt}, \mathrm{MgO}$ и $\mathrm{B} 2-\mathrm{NaCl}$ были использованы для перекрестной проверки полученных уравнений состояния. Построенные уравнения состояния девяти металлов, 

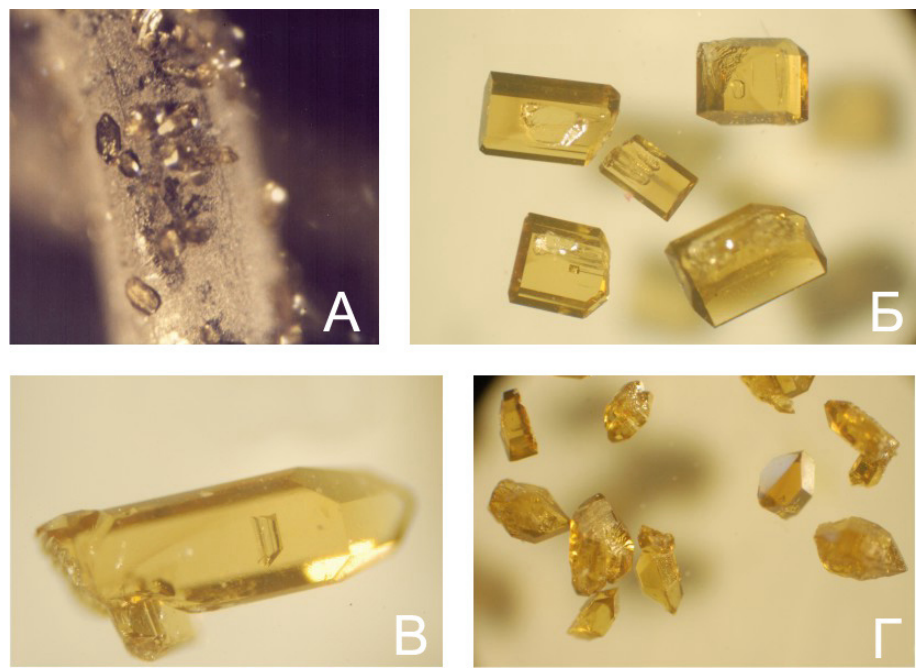

Рис. 5. Кристаллы фаялита на железосодержащих держателях образцов $(A-\Gamma)$.

| Fig. 5. Fayalite crystals on ferriferous clamps $(A-\Gamma)$.

алмаза, периклаза, B2-NaCl являются взаимосогласованными между собой и с рубиновой шкалой давлений [Dorogokupets et al., 2012; Sokolova et al., 2013]. Они используются при изучении P-V-T свойств твердых веществ и минералов в широкой области температур и давлений [Litasov et al., 2013].

Летников Ф.А., 2010 год - национальная экологическая премия «Экомир» за коллективную монографию «Экология человека в изменяющемся мире» в номинации «Экологическая наука и технологии».

Летников Ф.А., 2011 год - памятная медаль, посвященная 350-летию г. Иркутска; Медаль Президиума Сибирского отделения, посвященная 80-летию со дня рождения В.А. Коптюга.

\section{4. ПЕРСПЕКТИВЫ РАЗВИТИЯ ЛАБОРАТОРИИ}

Для решения одной из важнейших задач петрологии - реконструкции процессов преобразования литосферной мантии в разных сегментах Сибирского кратона - нужно активно внедрять современные аналитические методы: атомно-абсорбционный, экстракционно-атомно-абсорбционный анализы, масс-спектрометрию с индуктивно связанной плазмой (ICP-MS), а также спектральный и рентгенофлуоресцентный анализы для изучения микроэлементного состава интересующих типов пород и минералов. В экспериментальных исследованиях следует повысить температурные пределы до $1200{ }^{\circ} \mathrm{C}$ при давлениях порядка 0.4 ГПа, что вполне возможно при сравнительно небольших финансовых затратах. В лаборатории в течение послед-

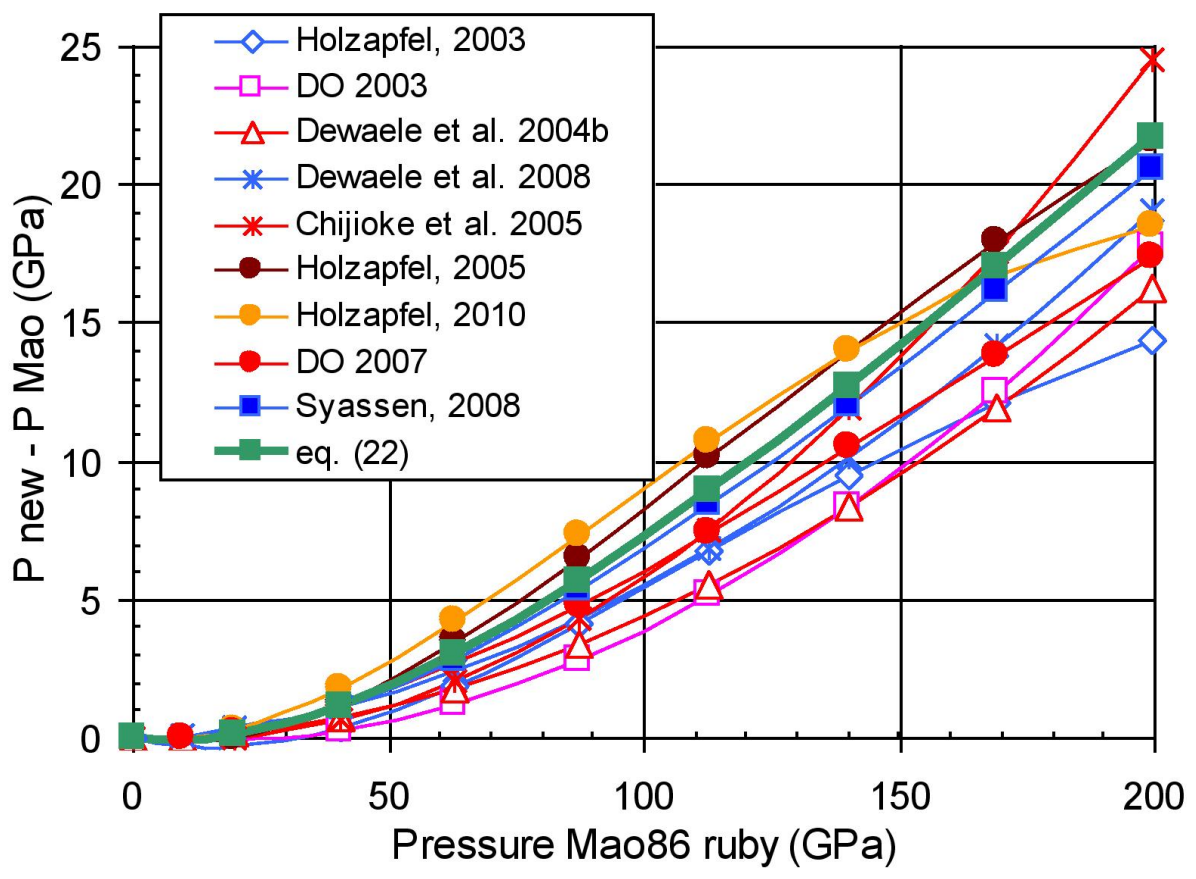

Рис. 6. Разница между современными калибровками рубиновой шкалы [Holzapfel, 2003, 2005, 2010; Dorogokupets, Oganov, 2003, 2007; Dewaele et al., 2004 b, 2008; Chijioke et al., 2005; Syassen, 2008] и классической рубиновой шкалой [Maо et al., 1986].

Fig. 6. Differences between recent calibrations of the ruby scale [Holzapfel, 2003, 2005, 2010; Dorogokupets, Oganov, 2003, 2007; Dewaele et al., 2004b, 2008; Chijioke et al., 2005; Syassen, 2008] and the classical ruby scale [Mao et al., 1986]. 
них лет активно разрабатываются уравнения состояния веществ и минералов. Тесное сотрудничество с К.Д. Литасовым (ИГМ СО РАН) позволяет использовать при разработке уравнений состояния минералов новые оригинальные экспериментальные измерения свойств минералов до давления 30 ГПа и температуры до $2000 \mathrm{~K}$.

\section{3. ЛАБОРАТОРИЯ ГЕОЛОГИИ И МАГМАТИЗМА ДРЕВНИХ ПЛАТФОРМ}

\section{1. ИСТОРИЧЕСКАЯ СПРАВКА}

Лаборатория геологии и магматизма древних платформ создана в 1971 г. на базе кабинета геологии и петрологии кимберлитов и алмазных месторождений. С 1971 по 1991 г. лабораторию возглавлял д.г.-м.н. Б.М. Владимиров (рис. 7). С 1991 г. заведующим лабораторией является кг.-м.Н. К.Н. Егоров. Сегодня в составе лаборатории (2014 г.) 17 сотрудников, из них 4 доктора и 3 кандидата наук (рис. 8).

Основными приоритетными направлениями фундаментальных исследований лаборатории являются: 1) состав, строение и эволюция кратонизированных областей Сибирской платформы; 2) структурно-вещественная типизация алмазоносных магматитов и конвергентных им пород, образующих генетические ряды в составе кимберлитовых, лампроитовых, карбонатитовых, щелочно-ультраосновных и щелочно-базальтоидных комплексов; 3) геолого-минералогическое районирование алмазоносных территорий югозападной части Сибирской платформы с целью создания теоретических основ прогноза и поисков коренной и россыпной алмазоносности.

\section{2. ОСНОВНЫЕ НАУЧНЫЕ ДОСТИЖЕНИЯ ЗА 2009-2013 ГГ.}

К главным достижениям лаборатории в XX и в начале XXI в. можно отнести: 1) прогнозирование и открытие в пределах юга Сибирской платформы алмазоносных лампроитов Ингашинского поля, а также россыпных проявлений алмазов и древних промежуточных коллекторов алмазов; 2) открытие Маконского кимберлитового поля с промышленной коренной и россыпной алмазоносностью в Лесной Гвинее (Западная Африка); 3) открытие нового минерала в кимберлитах - земкорита и первые находки пяти минералов для кимберлитов мира: журавскита, бассанита, гексагидрита, содалита, ферробрусита; 4) двухтомный коллективный монографический труд «Геология и генезис алмазных месторождений», за который Б.М. Владимиров удостоен Государственной премии СССР.

Важнейшие научные достижения лаборатории за пять предыдущих лет (2009-2013 гг.) приведены ниже.

Впервые выявлены минералого-геохимические и

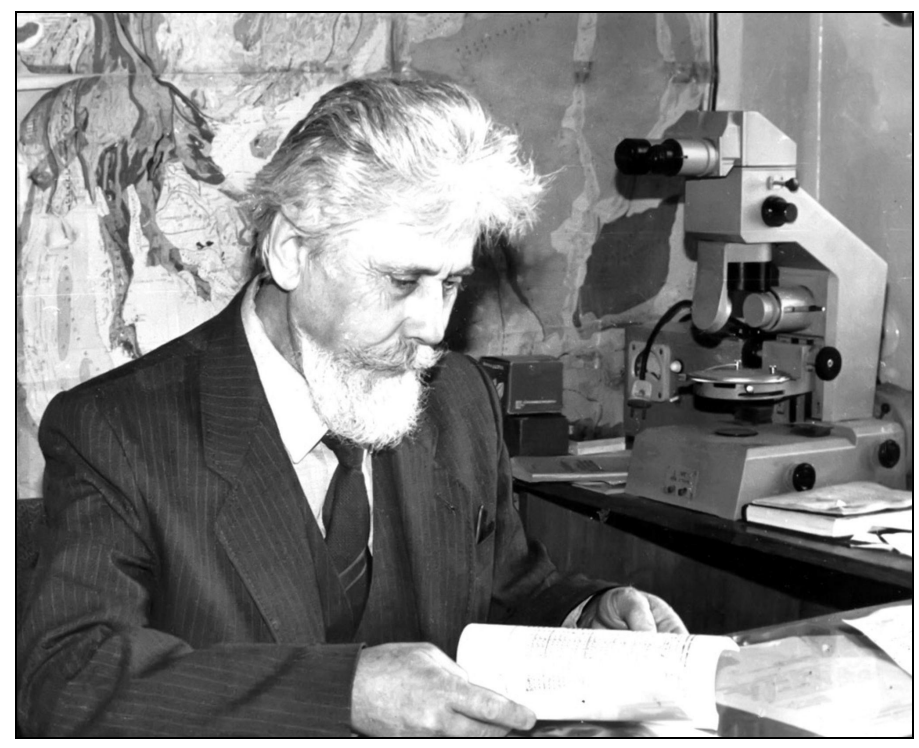

Рис. 7. Заведующий лабораторией геологии и магматизма древних платформ в 1971-1991 гг. д.г.-м.н. Борис Михайлович Владимиров.

Fig. 7. B.M. Vladimirov, Doctor of Geology and Mineralogy, Head of the Laboratory of Geology and Magmatism of Ancient Platforms from 1971 to 1991.

изотопно-геохимические признаки глубинных восстановленных углеродистых флюидных систем, преобразующих мантийную литосферу Сибирского кратона с формированием метасоматически переработанного субстрата, из которого впоследствии генерируются высокофлюидизированные кимберлитовые расплавы. Активное изотопно-геохимическое преобразование мантийной литосферы Сибирского кратона происходило на ранней стадии среднепалеозойского кимберлитового цикла. В этот период из астеносферных расплавов, активизированных в процессе подъема плюма, шел поток восстановленных горячих флюидов, которые экстрагировали ряд главных и редких элементов из пород и минералов литосферной мантии (рис. 9). Процессы изменения низов мантийной литосферы фиксируются значительным облегчением изотопов $\mathrm{O}_{2}$ в составе минералов перидотитов при активном воздействии флюидно-расплавных систем на границе литосфера-астеносфера в период кимберлитообразования. В мантийной литосфере Сибирского кратона проявлены два крупных этапа метасоматизма, которые привели к существенной химической и геохимической модификации ее первичного вещества. В первый этап процесс носил равновесный характер и был связан с образованием графита и алмаза, источником углерода которых были высокоплотные сверхкритические силикат-карбонатные флюиды-расплавы, а также углерод, выделявшийся из твердого раствора в первичных минералах. Силикат-карбонатные флюиды-расплавы вбирали в себя наиболее растворимые макро- и микро- 


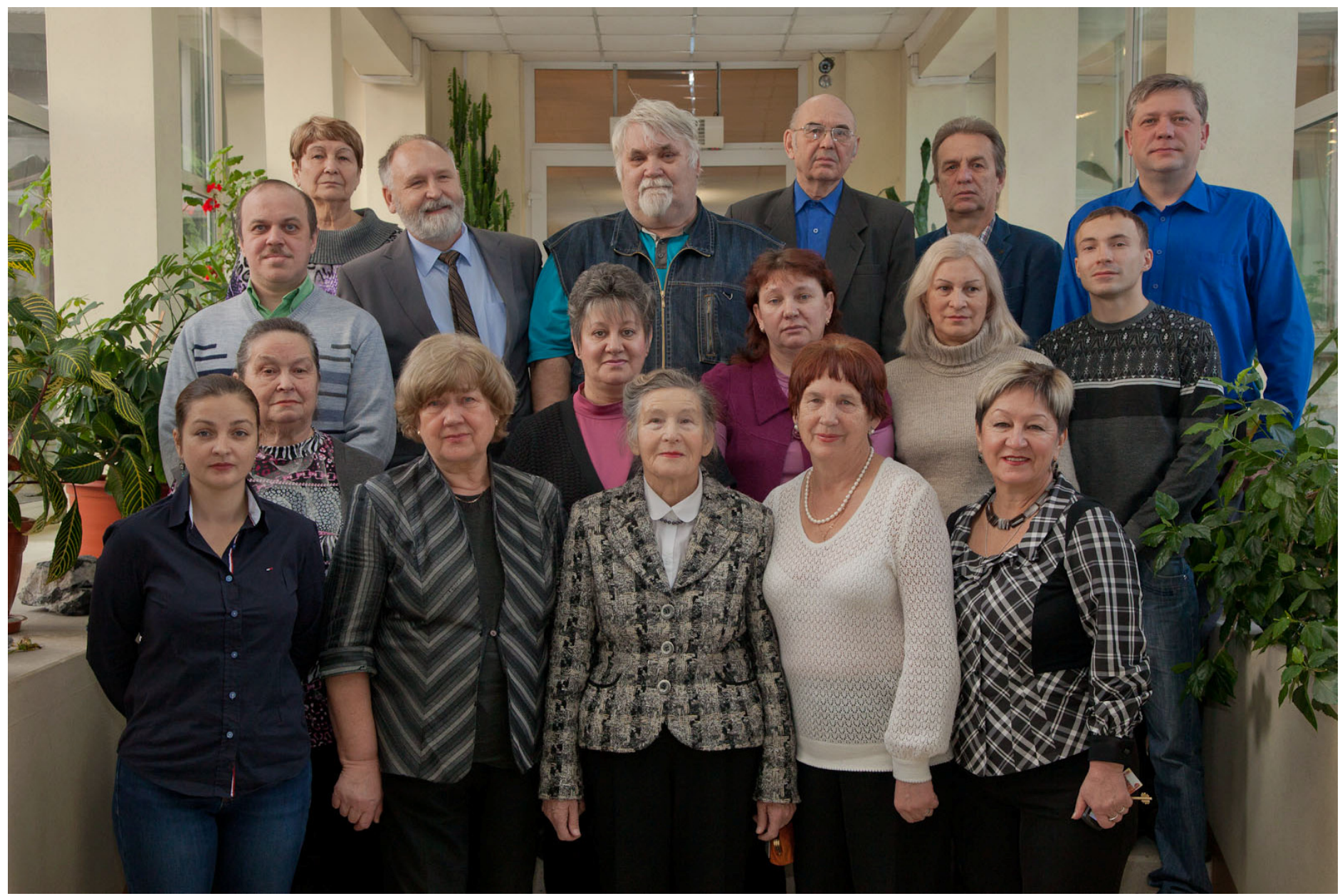

Рис. 8. Коллектив лаборатории геологии и магматизма древних платформ 2013 г. Слева направо, верхний ряд: С.Е. Глушенкова, д.г.-м.н. Н.И. Акулов, д.г.-м.н. А.И. Мельников, д.г.-м.н. А.И. Киселев, к.г.-м.н. К.Н. Егоров - зав. лабораторией, к.г.-м.н. Д.А. Кошкарев. Средний ряд: С.В. Тележников, О.А. Кузнецова, М.Г. Карнаушенко, И.А. Калашникова, Е.В. Антипин. Нижний ряд: Ю.А. Минаева, С.П. Сумкина, В.Г. Семенова, д.г.-м.н. Л.В. Соловьева, Г.В. Орлова, Т.М. Леви.

Fig. 8. The staff of the Laboratory of Geology and Magmatism of Ancient Platforms in 2013 (left to right): $1^{\text {st }}$ row: Yu.A. Minaeva, S.P. Sumkina, V.G. Semenova, L.V. Solovjeva, G.V. Orlova, T.M. Levi; $2^{\text {nd }}$ row - S.V. Telezhnikov, O.A. Kuznetsova, M.G. Karnaushenko, I.A. Kalashnikova, E.V. Antipin; $3^{\text {rd }}$ row - S.E. Glushenkova, N.I. Akulov, A.I. Mel'nikov, A.I. Kiselev, K.N. Egorov (Head of the Laboratory), and D.A. Koshkarev.

элементы и осуществляли интенсивный метасоматизм мантийной литосферы кратона. По времени этот процесс протекал одновременно с кратонизацией мантийной литосферы Сибирской платформы. Второй этап метасоматизма мантийной литосферы Сибирской платформы происходил на ранней стадии среднепалеозойского алмазообразующего цикла. В предкимберлитовый метасоматический этап кристаллизация основного объема алмазов связывается с реакциями окисления восстановленных флюидов, поступающих из астеносферных расплавов, на геохимических окислительных барьерах в зонах деформации мантийной литосферы [Solovyeva et al., 2010, 2012].

Впервые выявлены и сопоставлены составы мантийных источников расплавов двух крупнейших совмещенных провинций базальтового магматизма: пер- мо-триасовой Сибирской и девонской Вилюйской, а также локально проявленных кимберлитов и других магматических пород, сформировавшихся на флангах раннемеловой крупной изверженной провинции Высокой Арктики (HALIP) (рис. 10). Пространственное совмещение разновозрастных магматических ареалов дало уникальную возможность для сопоставления состава источников расплавов, последовательно проявившихся под одним и тем же литосферным сегментом. Глубинные источники всех разновозрастных магматических ареалов, продукты которых оказались совмещенными в северо-восточной части Сибирского кратона, имеют различные изотопно-геохимические составы (рис. 11). Локальный апвеллинг плюма под областями с утоненной литосферой Сибирского кратона вследствие высокого температурного градиента со- 

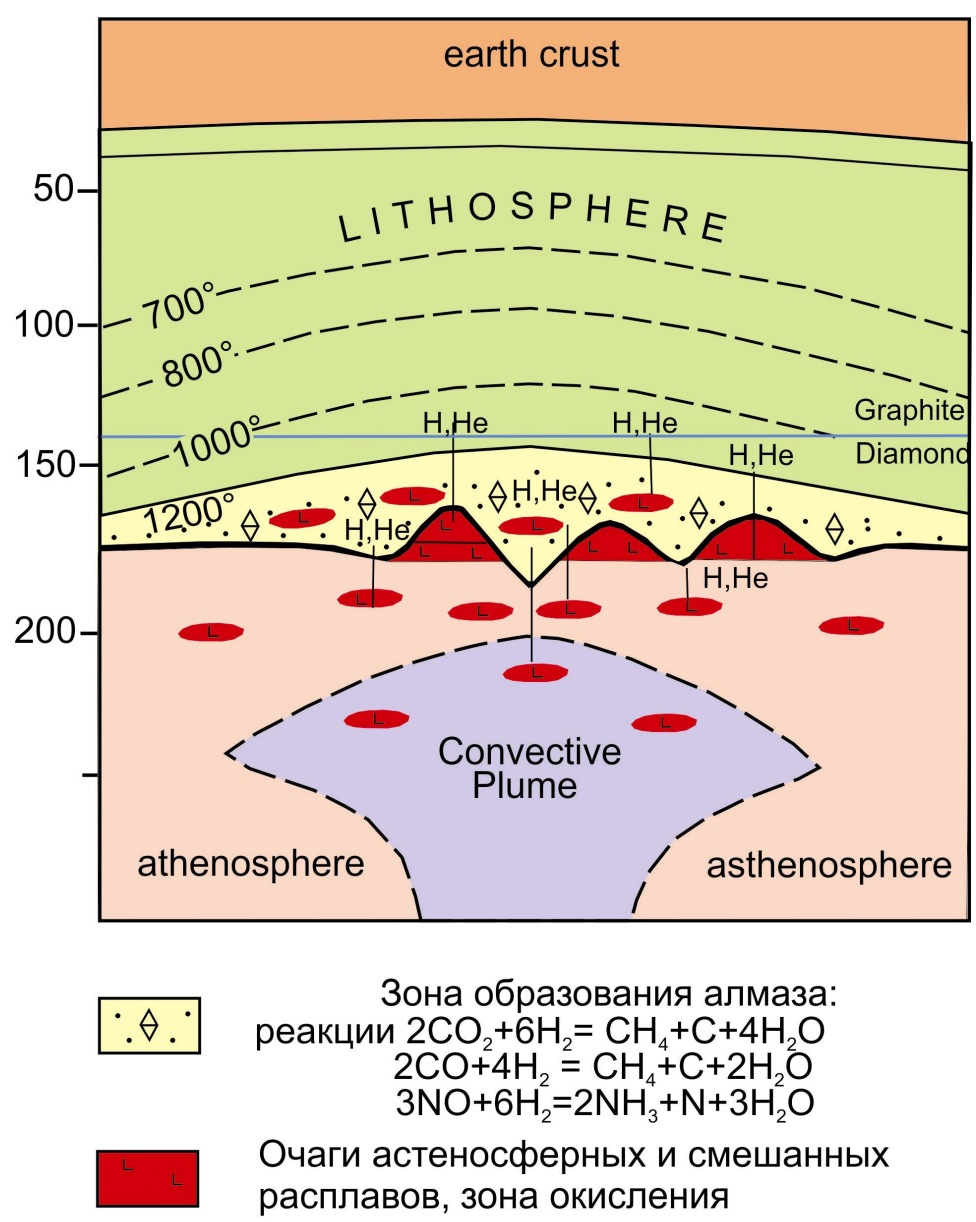

— Граница: литосфрера - астеносфрера

Рис. 9. Модель флюидно-магматического преобразования астеносферных слоев и литосферной мантии Сибирского кратона в период среднепалеозойского кимберлитообразующего цикла.

Fig. 9. The model of fluid-magmatic transformation of the asthenosphere layers and the lithospheric mantle of the Siberian craton in the Middle Paleozoic kimberlite cycle.

провождался более высокой степенью адиабатического плавления и появлением базальтовых расплавов, образующих магматические очаги и субаэральный вулканизм. Прекращение подъема плюма под архейскими террейнами с мощной тугоплавкой литосферой происходило на более глубинных уровнях. Здесь из-за повышенного давления вещество плюма подвергалось более низкой степени частичного плавления. В этих условиях образование кимберлитовой магмы было связано с участием в плавлении относительно холодных периферических частей латерально растекающейся головы плюма и метасоматически обогащенной кратонной литосферы. Пространственно-временная сопряженность кимберлитовых и базитовых магм относится к пограничной области перехода от толстой кратонной литосферы архейских террейнов к областям относительно тонкой литосферы палеопротерозойских орогенных поясов, испытавшей последующее утонение в результате мезо- и неопротерозойского рифтинга в пределах Сибирского кратона. Последовательность магматизма в пределах Якутской алмазоносной провинции от массовых территориально широких проявлений базитов к ограниченным полям алмазоносных кимберлитов связана с уменьшением термальной активности плюма во времени и заглублением уровней магмообразования, а также с плавлением фрагментов деламинированной литосферы, погруженных в головную часть плюма [Kiselev et al., 2010, 2012; Egorov et al., 2010].

В пределах южной окраины Сибирского кратона выполнены первые оценки состава и геохимической специфики магматических источников, алмазоносности и геодинамических условий формирования продуктов разнотипного полихронного (R, V, Pz) высококалиевого мантийного магматизма. На территории Восточного Присаянья выделено несколько этапов внедрения алмазоносных лампроитов и кимберлитов: мезопротерозой (средний рифей, около 1200 млн лет), 


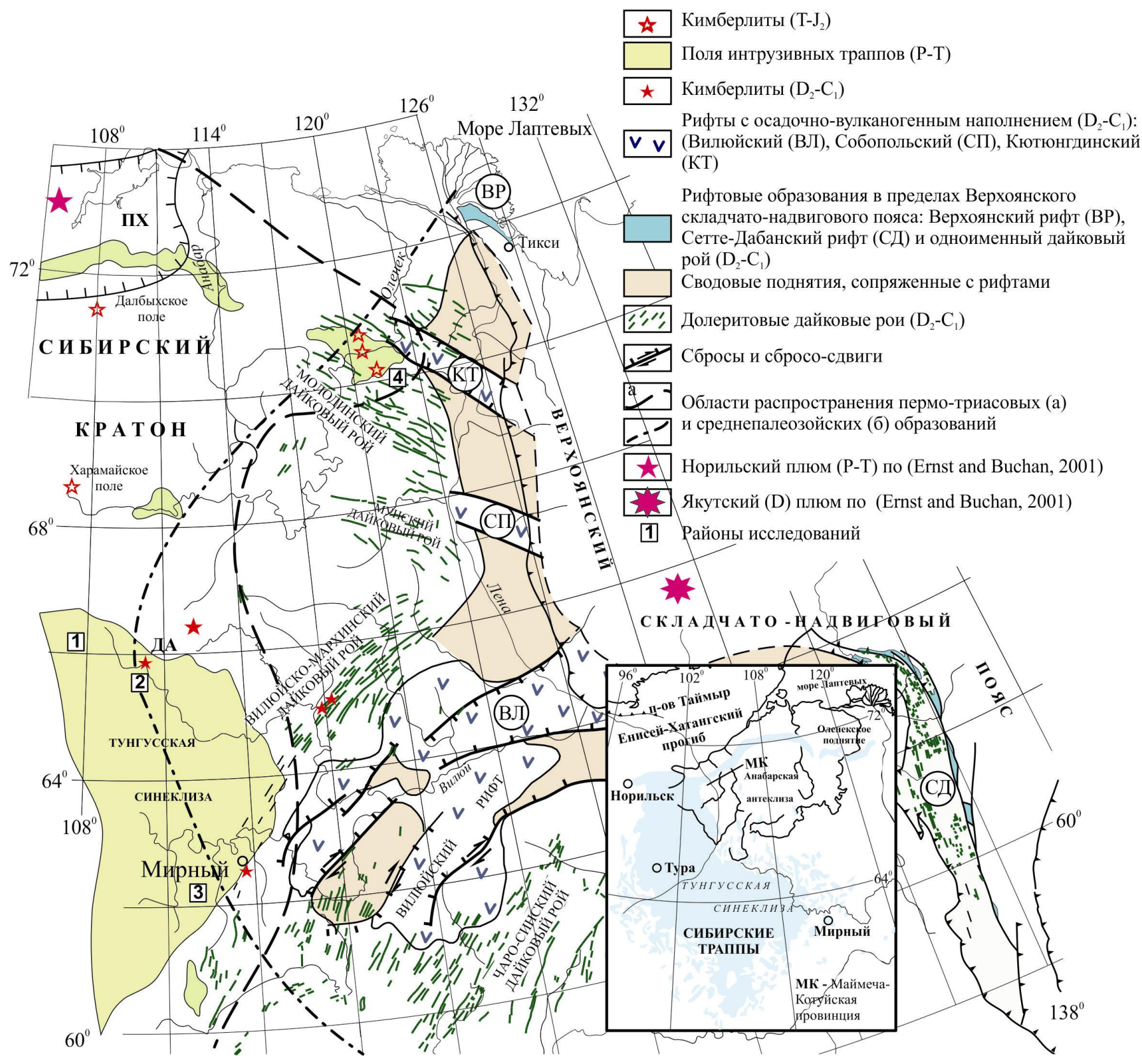

Рис. 10. Расположение пермо-триасовых и девонских магматических ассоциаций в пределах восточной части Сибирского кратона (на врезке показано распространение траппов в пределах Сибирского кратона).

Fig. 10. Locations of the Perm-Triassic and Devonian magmatic associations within the limits of the eastern part of the Siberian craton (the insert shows trapp areas within the limits of the Siberian craton).

неопротерозой (венд, около 630 млн лет) и средний палеозой (девон, около 370 млн лет) (рис. 12). Существование двух (среднерифейской и среднепалеозойской) эпох тектономагматической активности, сопровождающейся формированием алмазоносных лампроитовых и кимберлитовых тел в пределах южной окраины Сибирской платформы, подтверждается наличием «древних» докембрийских и фанерозойских типов алмазов в россыпях р. Бирюса и Ингашет (рис. 13, 14). Полученные данные свидетельствуют о том, что уже 2.1-2.0 млрд лет назад в литосферной мантии южной окраины Сибирского кратона в ходе плюм-литосферного взаимодействия сформировались метасоматизированные области, обогащенные некогерентными элементами и способные генерировать разнообразные калиевые магматиты. Модельный возраст $\mathrm{T}_{\mathrm{Nd}}(\mathrm{DM})$ обогащения мантийных источников алмазоносных лампроитов, лампроитоидов и потенциально алмазоносных слюдяных кимберлитов варьируется от 2.1 до 1.8 млрд лет и совпадает по времени с коллизией архейских и раннепротерозойских террейнов южной окраины Сибирского кратона. Следует особо подчеркнуть, 


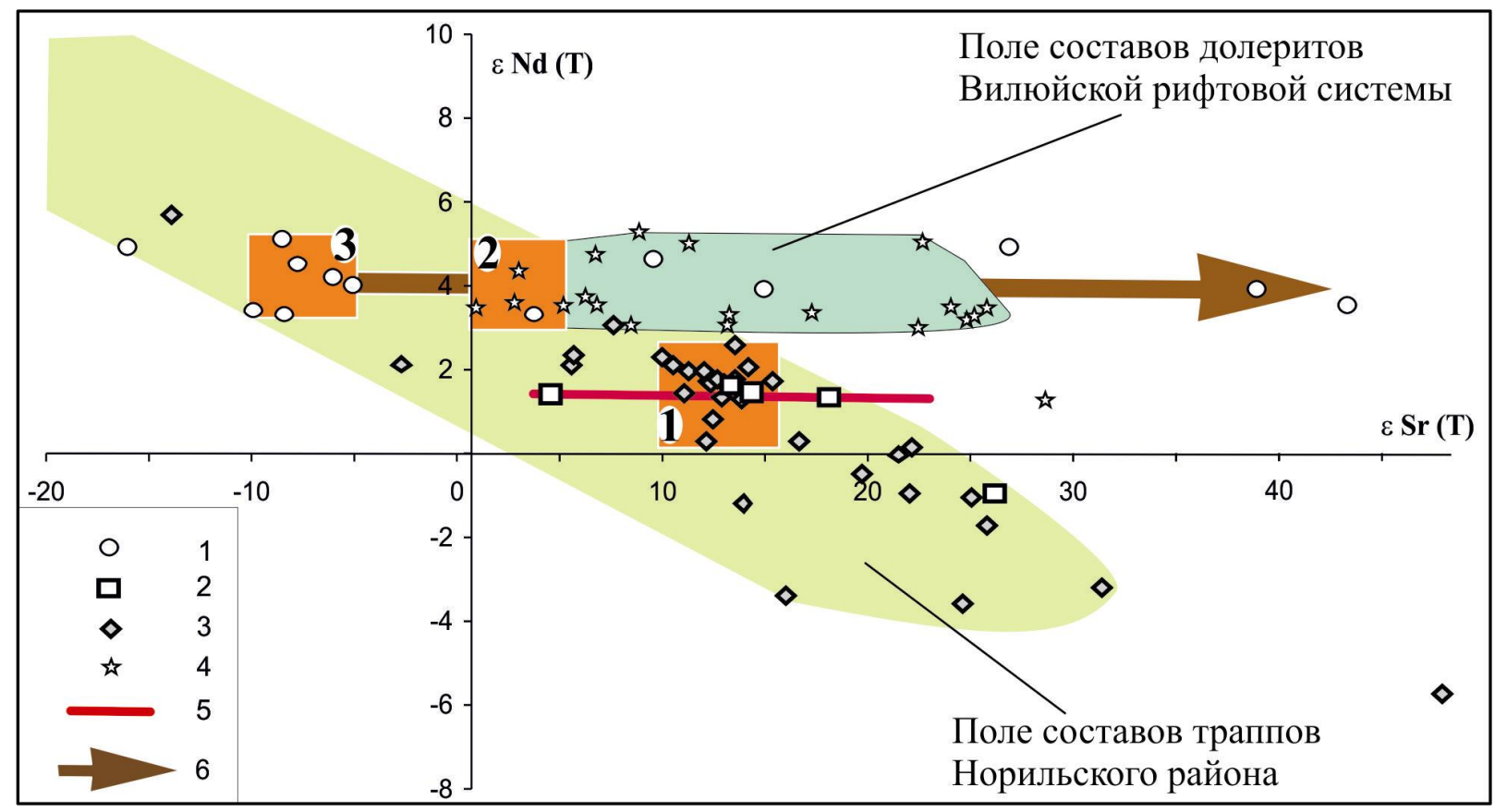

Рис. 11. Эпсилон $\mathrm{Nd}(\mathrm{T})$ - эпсилон $\operatorname{Sr}(\mathrm{T})$ диаграмма для кимберлитов, траппов и долеритов Вилюйской рифтовой системы.

1 - позднемезозойские кимберлиты; 2 - траппы восточной окраины Тунгусской синеклизы; 3 - траппы Норильского района; 4 - девонские долериты и кимберлиты Мирнинского кимберлитового поля; 5 - тренд вариаций составов траппов восточной окраины Тунгусской синеклизы; 6 - тренд вариаций составов позднемезозойских кимберлитов Оленекского поднятия. Квадраты 1, 2, 3 - глубинные источники траппов, девонских долеритов и позднемезозойских кимберлитов соответственно.

Fig. 11. The epsilon $\mathrm{Nd}(\mathrm{T})$ - epsilon $\mathrm{Sr}(\mathrm{T})$ diagram for kimberlites, trapps and dolerites of the Viluj rift system.

1 - the Late Mesozoic kimberlites; 2 - trapps at the eastern margin of the Tunguska syncline; 3 - trapps of Norilsk region; 4 - the Devonian dolerites and kimberlites of the Mirny kimberlite field; 5 - trends of trapp composition variations for the eastern part of the Tunguska syncline; 6 trends of composition variations of the Late Mesozoic kimberlites of the Olenyok uplift. Boxes 1, 2, and 3 show deep sources of trapps, the Devonian dolerites and Late Mesozoic, respectively.

что алмазоносные и потенциально алмазоносные породы южной окраины Сибирского кратона имеют общие изотопно-геохимические признаки, резко отличные от бесперспективных слюдяных пикритов и щелочных пород белозиминского комплекса Присаянья, что является надежным прогностическим критерием коренных источников алмазов [Egorov et al., 2010].

На основе обобщения многолетних результатов комплексного картирования структурно-тектонического околотрубочного пространства и внутреннего строения кимберлитового комплекса месторождения алмазов трубки «Удачная» (1979-2009 гг.) выделены три этапа структурно-вещественной эволюции всего рудного узла в целом. Первый этап проявления кимберлитового магматизма в районе трубки «Удачная» связан с формированием мощной северо-восточной системы разрывных нарушений, пространственно контролирующей большинство дотрубочных кимберлитовых жил и сателлитные «слепые» кимберлитовые тела (рис. 15). На втором этапе происходило внедрение основного объема кимберлитовых фаз трубки «Удачная» в условиях растяжения на фоне пульсационного развития сдвиговых смещений по северо-восточному разлому (рис. 15). С третьим этапом связана пермо-триасовая активизация северо-западной системы разломов и внедрение позднепалеозойских-раннемезозойских даек долеритов и в последующем жилы калиевых трахитов мелового возраста (рис. 16). По изотопному составу жильных кимберлитов $\left(\varepsilon \mathrm{Nd}=4.2,{ }^{87} \mathrm{Sr} /{ }^{86} \mathrm{Sr}(\mathrm{t})=0.7050\right)$ их мантийный источник соответствует умеренно деплетированной мантии. Модельный возраст $\mathrm{T}_{\mathrm{Nd}}(\mathrm{DM})$ обогащения мантийного источника кимберлита равен 651 млн лет. Сформированные на более позднем этапе слюдяные кимберлиты имеют обогащенный мантийный источник $\left(\varepsilon N d=0.2,{ }^{87} \mathrm{Sr} /{ }^{86} \mathrm{Sr}(\mathrm{t})=0.7078\right)$ с модельным возрастом, равным 924 млн лет. Следует подчеркнуть, что на геохимические и изотопно-геохимические характеристики различных геолого-промышленных типов кимберлитов трубки «Удачная» заметно влияют рассолы второго водоносного горизонта месторождения. В целом, образование основного объема кимберлитов в виде отдельных трубок, жил или самостоятельных фаз внедрения произошло во второй этап кимберлитового магматизма Далдынского кимберлитового поля. Процессами эрозии были уничтожены главным образом незначительные объемы малопро- 


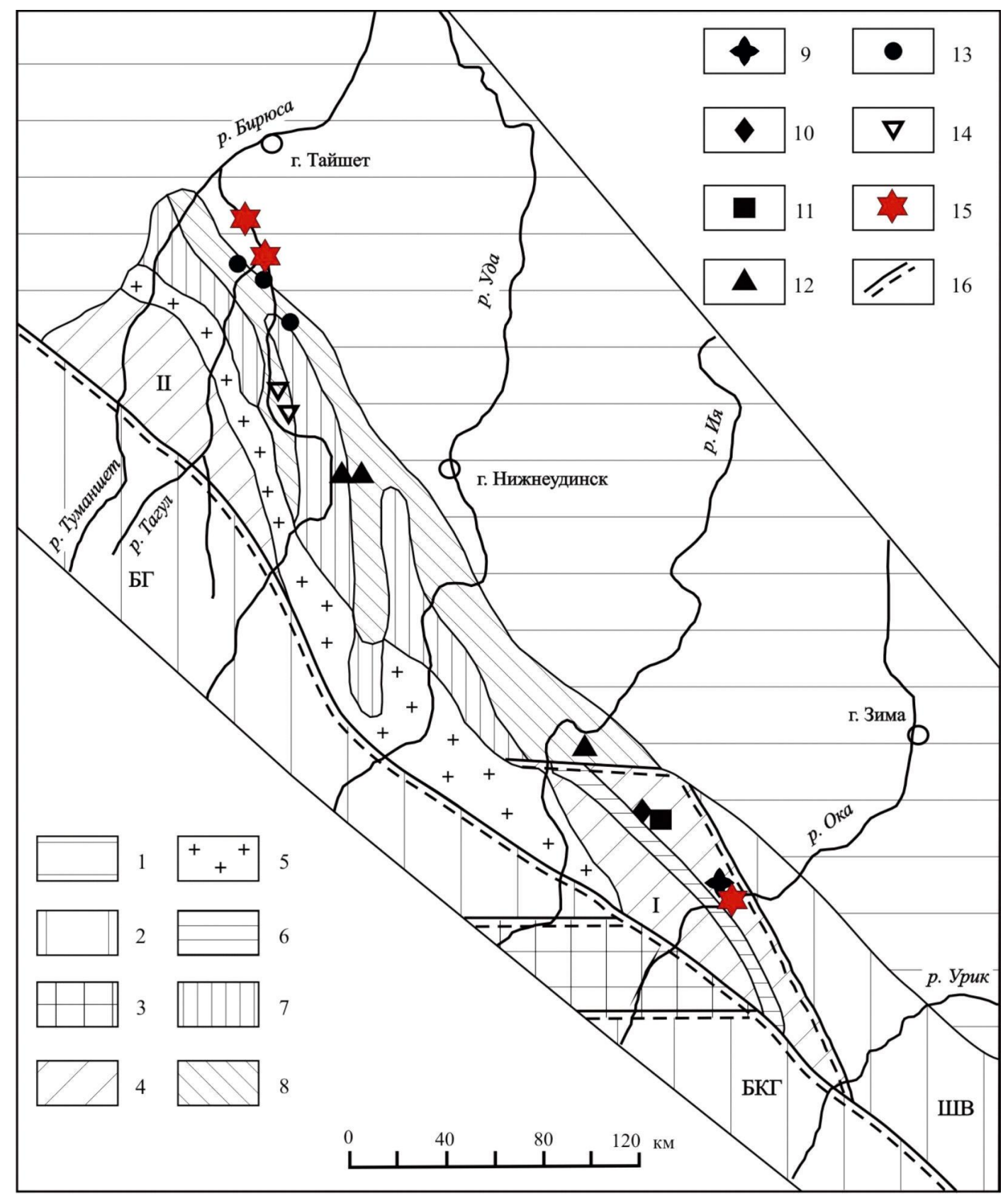

Рис. 12. Схема размещения калиевых ультрабазитов и базитов в пределах юго-западной окраины Сибирского кратона.

1 - фанерозойский осадочный чехол; 2 - раннедокембрийские гранитогнейсовые комплексы (БГ - Бирюсинская глыба, БГК - БельскоКитойская глыба, ШВ - Шарыжалгайский выступ); 3 - отложения Хамсаринского синклинория (кембрий-карбон); 4 - грабены раннего протерозоя Урикско-Туманшетской перикратонной зоны (I - Урикско-Ийский, II - Туманшетский); 5 - гранитогнейсовый вал (нижнепротерозойский саянский комплекс); 6 - вулканогенно-осадочные образования нижнерифейской рифтогенной структуры; 7 - карагасская серия Присаянского прогиба (верхний рифей); 8 - оселковая серия Присаянского прогиба (венд); 9 - алмазоносные лампроиты р. Ингаши (средний рифей); 10 - кимберлиты р. Ярма (венд); 11 - щелочные ультраосновные породы и карбонатиты зиминского комплекса (верхний рифей - венд); 12 - ультракалиевые трахиты (верхний рифей); 13 - лампроитоиды Присаянского прогиба (средний девон); 14 - слюдяные пикриты р. Туманшет (средний рифей); 15 - места находок алмазов; 16 - крупнейшие разломы.

Fig. 12. Locations of potassium ultra-basic and basic rocks within the limits of the south-western margin of the Siberian craton.

1 - the Phanerozoic sedimentary cover; 2 - the Early Pre-Cambrian granite-gneiss complexes (БГ - Biryusa rock, БГК - Belsko-Kitoy rock, ШВ - Sharyzhalgai horst); 3 - deposits of the Khamsara syncline (Cambrian-Carbon); 4 - the Late Proterozoic grabens of the Urik-Tumanshet pericraton zone (I - Yrik-Ijsky, II - Tumanshetsky); 5 - granite-gneiss embankment (the Low Proterozoic Sayansky complex); 6 - volcanogenicsedimentary formations of the Low Riphean riftogenic structure; 7 - Karagasskaya series of the Prisayansky trough (Upper Riphean); 8 - Oselkovaya series of the Prisayansky trough (Vendian); 9 - diamond-bearing lamproites of the Ingashi river (Middle Riphean); 10 - kimberlites of the Yarma river (Vend); 11 - alkaline ultra-basic rocks and carbonatites of the Ziminsky complex (Upper Riphean - Vend); 12 - ultra-potassium trachytes (Upper Riphean); 13 - lamproitoids of the Prisayansky trough (Middle Devonian); 14 - mica picrites of the Tumanshet river (Middle Riphean); 15 - sites where diamonds were found; 16 - largest faults. 

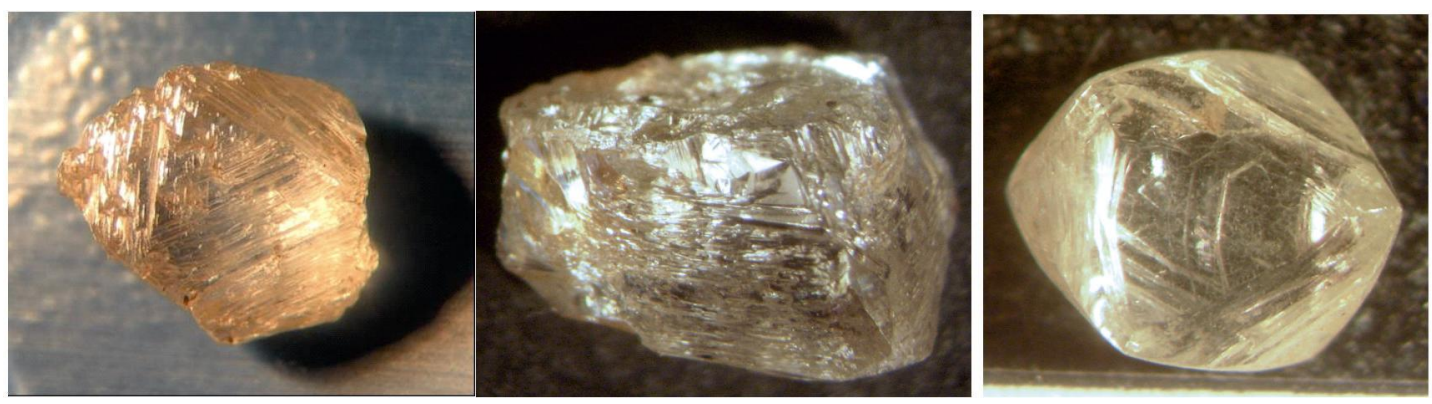

Рис. 13. Морфогенетические особенности алмазов октаэдрического габитуса из Ингашетской россыпи (среднепалеозойский кимберлитовый коренной источник якутского типа).

Fig. 13. Specific morphogenetic features of diamonds of the octahedral habitus from the Ingeshet placer (Middle Paleozoic kimberlitic ore body of the Yakutian type).

дуктивных интрузивных разновидностей кимберлитов первого этапа, которые создавали небольшие ореолы рассеяния минералов-спутников и не могли образовывать промышленно-алмазоносные россыпи в Далдынском поле [Egorov, Melnikov, 2013; Kopylova et al., 2013].

В пределах самого крупного коренного месторождения алмазов Якутии - кимберлитовой трубки «Юбилейная» - выделены четыре геолого-технологических типа руд, которые представлены порфировыми кимберлитами, кимберлитовыми брекчиями и двумя разновидностями автолитовых кимберлитовых брекчий (рис. 17). По данным изучения керновых проб эксплоразведки и выхода коммерческой продукции промышленной фабрики впервые установлено, что различные типы руд в трубке «Юбилейная» отличаются между собой не только по общему содержанию алмазов, но и по его ситовым характеристикам. В трубке «Юбилейная» надежно устанавливается увеличение содержания и одновременно крупности алмазов от ранних фаз внедрения кимберлитов к более поздним. На верхних и средних горизонтах центральной, а также западной части месторождения высокопродуктивные автолитовые брекчии часто выполняют мощные инъекции между крупными ксенолитами осадочных пород и забалансовыми кимберлитовыми рудами. Подобная геологическая ситуация приводит к необходимости оперативного пересмотра сортности руд, их селективной выемки и постоянного контроля по оптимизации процессов рудоподготовки и обогащения. Полученные данные по алмазоносности геолого-технологических типов руд используются при выборе технологических схем обогащения и методов извлечения алмазов, обеспечивающих максимальную степень их сохранности [Koshkarev et al., 2010].

Детальный анализ перспектив на обнаружение коренной алмазоносности юго-западной части Сибирской платформы с использованием комплексных геолого-геофизических, структурно-тектонических и минерагенических материалов позволил выделить блоки алмазоносной и потенциально алмазоносной мантийной литосферы в региональных прогнозных структу-
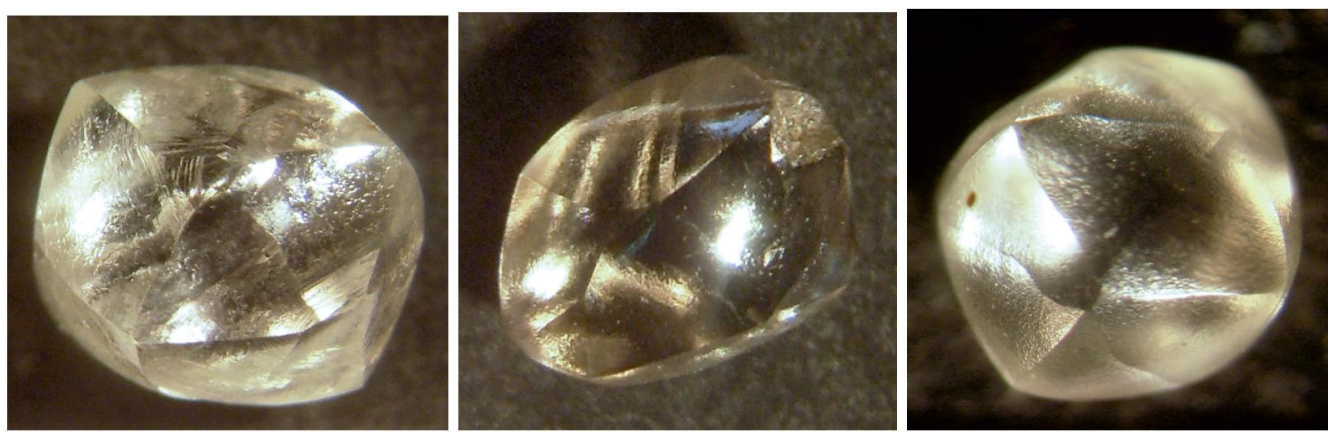

Рис. 14. Морфогенетические особенности алмазов додекаэдрического габитуса из Ингашетской россыпи (докембрийский лампроитовый или кимберлитовый архангельского типа коренной источник).

Fig. 14. Specific morphogenetic features of diamonds of the dodecahedral habitus from the Ingeshet placer (Pre-Cambrian lamproitic or kimberlitic ore body of the Arkhangelsk type). 


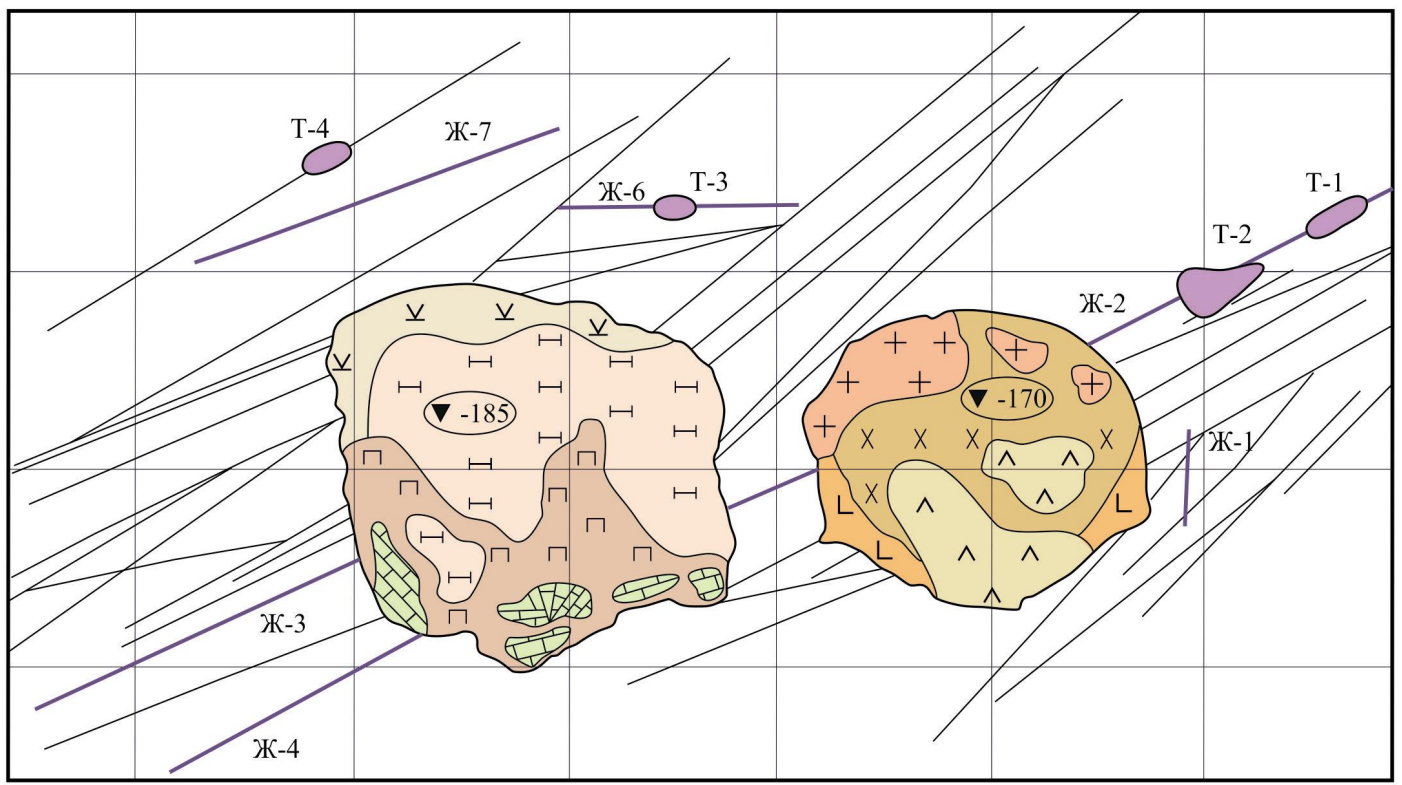

6
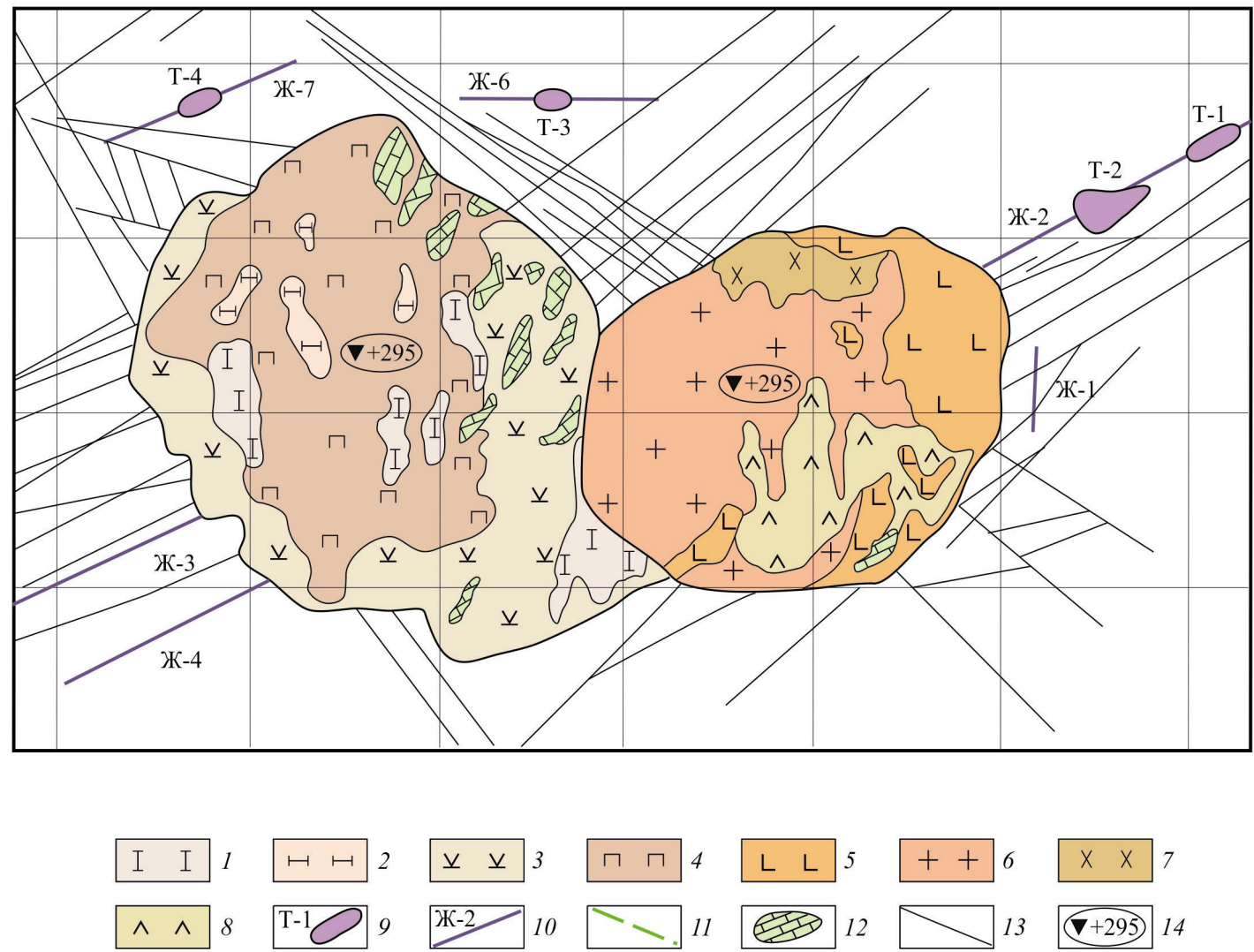

Рис. 15. Первый (a) и второй (б) этапы формирования разрывных нарушений и кимберлитового комплекса месторождения алмазов трубки «Удачная».

1-4 - типы кимберлитов трубки «Удачная-Западная»; 5-8 - типы кимберлитов трубки «Удачная-Восточная»; 9 - «слепые» сателлитные кимберлитовые тела; 10 - кимберлитовые жилы; 11 - дайки долеритов и трахитов; 12 - рифы осадочных пород; 13 - разрывные нарушения; 14 - абс. отметки эксплуатационных горизонтов.

Fig. 15. First ( $a$ ) and second (б) stages of faulting and formation of the kimberlitic complex of the Udachnaya diamond pipe deposit.

1-4 - types of kimberlites of the Western Udachnaya pipe; 5-8 - types of kimberlites of the Eastern Udachnaya pipe; 9 - 'blind-type' satellite kimberlitic bodies; 10 - kimberlitic veins; 11 - dykes of dolerites and trachytes; 12 - sedimentary rock stacks; 13 - faults; 14 - absolute elevations of production horizons. 


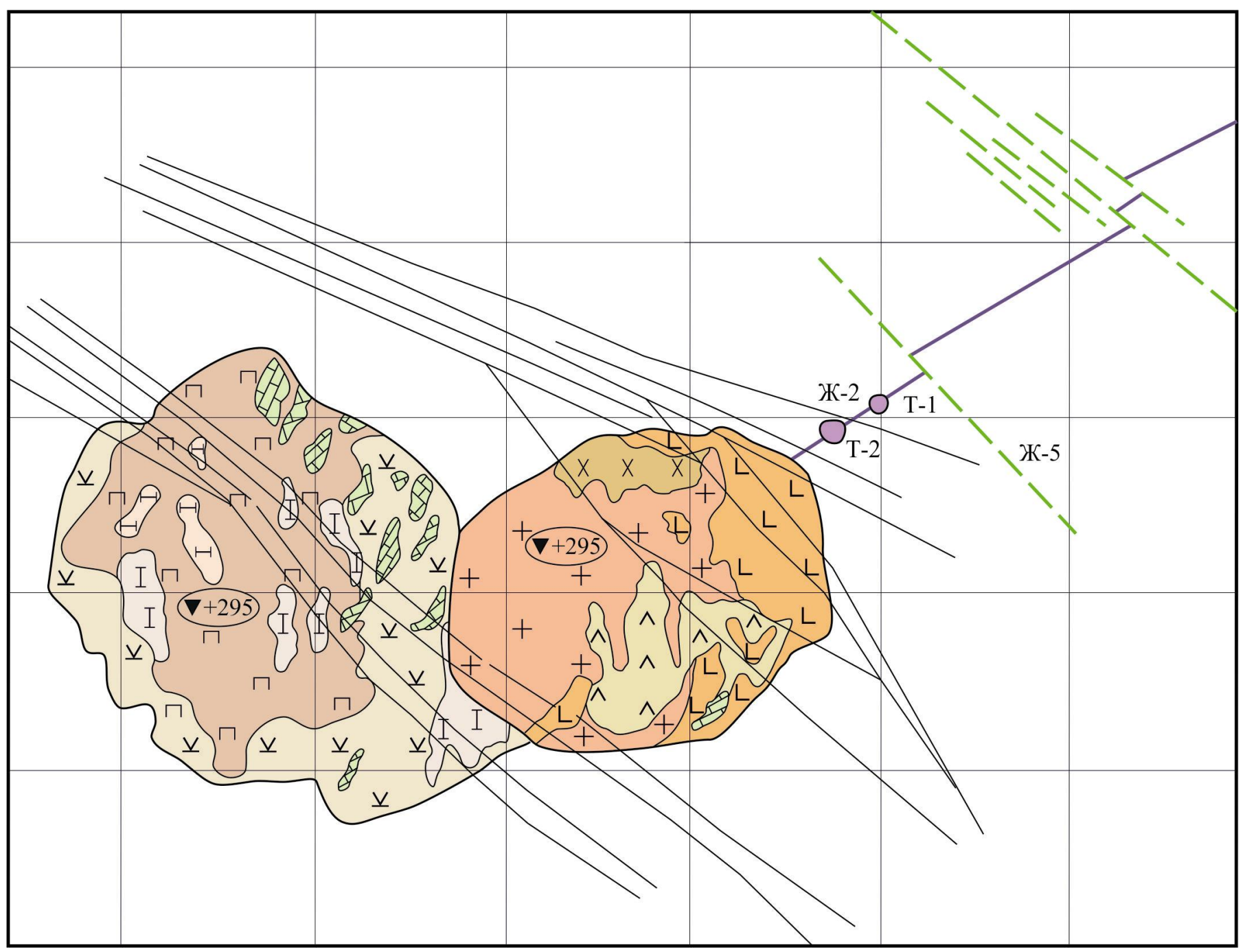

Рис. 16. Третий этап формирования разрывных нарушений и внедрение позднепалеозойских-раннемезозойских даек долеритов, жилы (Ж-5) калиевых трахитов мелового возраста в районе трубки «Удачная» (условные обозначения см. на рис. $15, a$, б).

Fig. 16. The third stage of faulting and intrusion of the Late Paleozoic-Early Mesozoic dykes of dolerites, and veins (Ж-5) of the Carboniferous potassium trachytes in the area of the Udachnaya pipe (see the legend in Fig. 9, $a$, б).

рах - минерагенических алмазоносных зонах (рис. 18). Алмазный потенциал минерагенических зон охарактеризован с точки зрения наличия кимберлитового и лампроитового магматизма, а также россыпных проявлений алмазов, которые служат критериями для обоснованного прогнозирования алмазоносных коренных источников различных геолого-генетических типов. Результаты комплексного изучения состава, морфологии и характера распределения индикаторных минералов и алмазов на юге Сибирской платформы позволяют считать, что для каждой из выделенных минерагенических зон существуют и/или прогнозируются самостоятельные коренные источники алмазов и их минералов-спутников, резко отличных друг от друга по вещественно-индикационным признакам. Для оценки коренной алмазоносности юга Сибирской платформы впервые использован редкоземельный состав пиропов из алмазоносных лампроитов Ингашинского поля и древних ореолов рассеяния минералов-спутников алмаза Тангуй-Чукшинской и Мурской площади. В пределах этих площадей прогнозируются среднепалеозойские алмазоносные кимберлитовые тела, типоморфные минералы которых образуют локальные ореолы в терригенных отложениях раннекарбонового возраста [Koshkarev et al., 2010; Egorov et al., 2012].

Впервые в пределах северо-восточного обрамления Сибирской платформы установлен новый тип коренных источников алмазов, представленный осадочновулканогенными отложениями карнийского яруса верхнего триаса. По комплексу вещественно-индикационных признаков алмазоносные породы относятся к туффитам с литокластами гиалобазальтов, трахиба- 


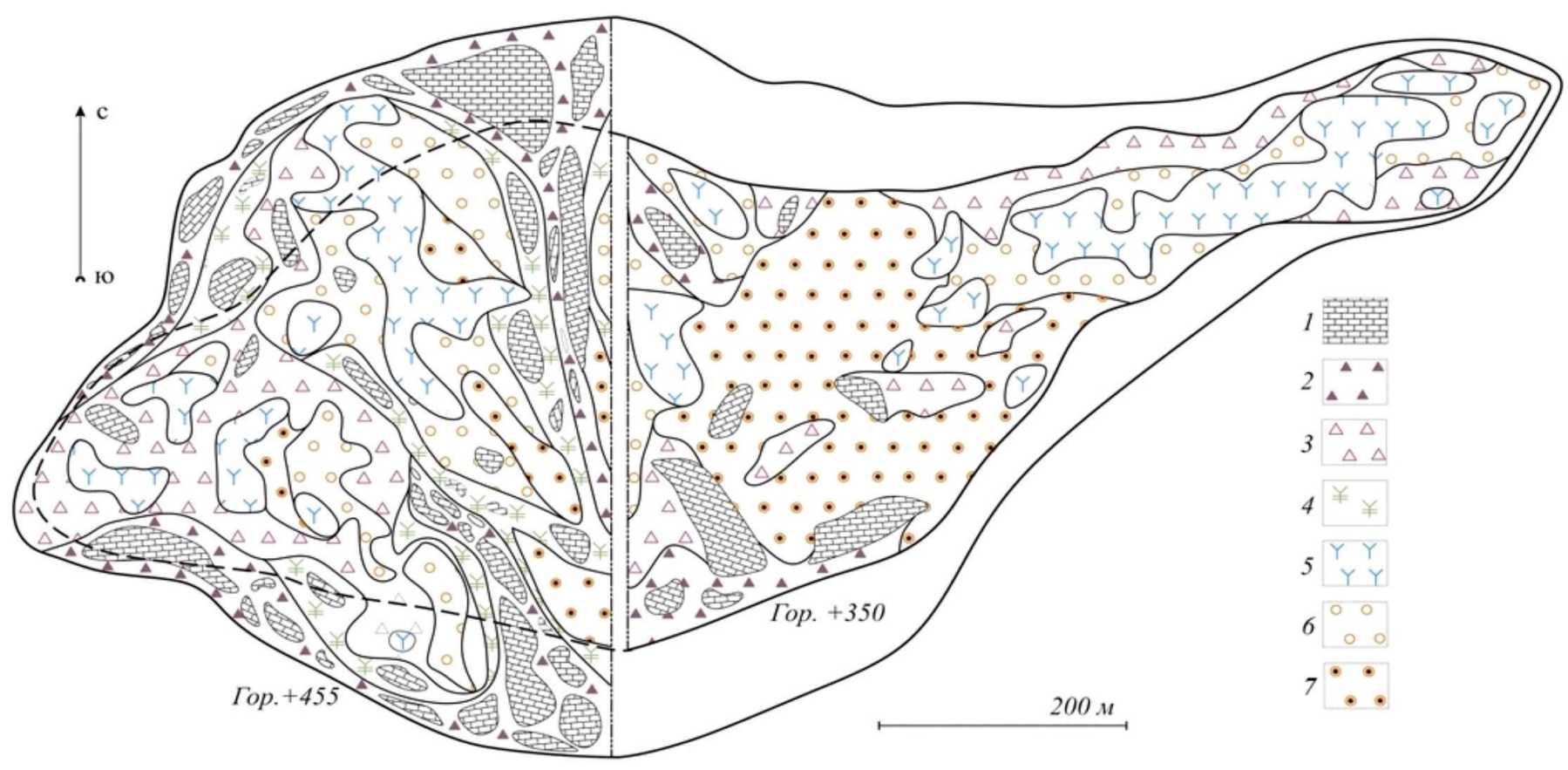

Рис. 17. Геологическое строение верхних (+455) и средних (+350) горизонтов трубки «Юбилейная».

1 - крупные ксенолиты вмещающих осадочных пород; 2 - ксенолитонасыщенные кимберлитовые брекчии (количество ксенолитов от 25 до 80 об. \%); 3 - кимберлитовые брекчии с содержанием ксенолитов менее 25 об. \%; 4 - афировые и шлирово-такситовые кимберлиты; 5 - порфировые кимберлиты; 6 - автолитовые кимберлитовые брекчии промежуточной фазы внедрения; 7 - автолитовые кимберлитовые брекчии поздней фазы внедрения.

Fig. 17. Geology of the top (+455) and medium (+350) horizons of the Yubileynaya pipe.

1 - large xenoliths of host sedimentary rocks; 2 - xenolith-saturated kimberlitic breccia (xenolith content from 25 to $80 \%$ of the volume); 3 - kimberlitic breccia with xenolith contents below $25 \%$ of the volume; 4 - aphyric and schlieren-taxite kimberlites; 5 - porphyritic kimberlites; 6 - autholith kimberlitic breccia of the intermediate phase of intrusion; 7 - autholith kimberlitic breccia of the late phase of intrusion.

зальтов, сцементированных преимущественно железистым хлоритом, гидрослюдой, анальцимом, ярозитом. Петрогеохимический состав туффитов не позволяет однозначно идентифицировать их с известными промышленно алмазоносными магматическими породами. Туффиты характеризуются высоким содержанием пиропов, хромитов, а также ураганными концентрациями несортированных алмазов (более $10 \mathrm{kap} / \mathrm{m}^{3}$ ). Среди алмазов отмечается повышенное количество кристаллов V и VII разновидности с легким изотопным составом углерода. В результате размыва нетрадиционного коренного источника алмазов сформированы современные промышленные россыпные месторождения северо-восточной части Сибирской платформы [Grakhanov et al., 2010].

Установлены вещественные признаки новой импактной структуры на юге Сибирской платформы в виде локализованного ареала распространения неизношенных обломков шлакоподобных пород ударнометаморфогенной природы. Среди обломков импактитов выделены витрокластические и литовитрокластические разновидности зювитов. Витрокластические разновидности представлены стекловатым матриксом, включающим скелетные, дендритовидные образования армолколита, а также обособления кремнийсодержащего титаномагнетита. Сферические выделения самородного железа обнаружены почти во всех армолколитсодержащих стеклах зювитов (рис. 19). Отличительной особенностью витрокластических зювитов является присутствие в них редких сферул самородного алюминия и отсутствие ильменита. Область распространения обломков зювитов совпадает с Игинтейской купольно-кольцевой морфоструктурой центрального типа размером $22 \times 27$ км. Вещественные и геологоструктурные признаки кольцевой структуры АнгароУдинского междуречья свидетельствуют о возможном взрыве крупного космического объекта (кометы, астероида) над территорией юго-западной части Сибирской платформы. Судя по морфологическим признакам обломков зювитов и геологическому строению территории Ангаро-Удинского междуречья, данное катастрофическое природное явление могло произойти начиная с юрского времени до неогена. Таким образом, на рубеже мезозоя и кайнозоя могли произойти глобальные события, которые способствовали изменению эволюционной линии жизни, в частности на 


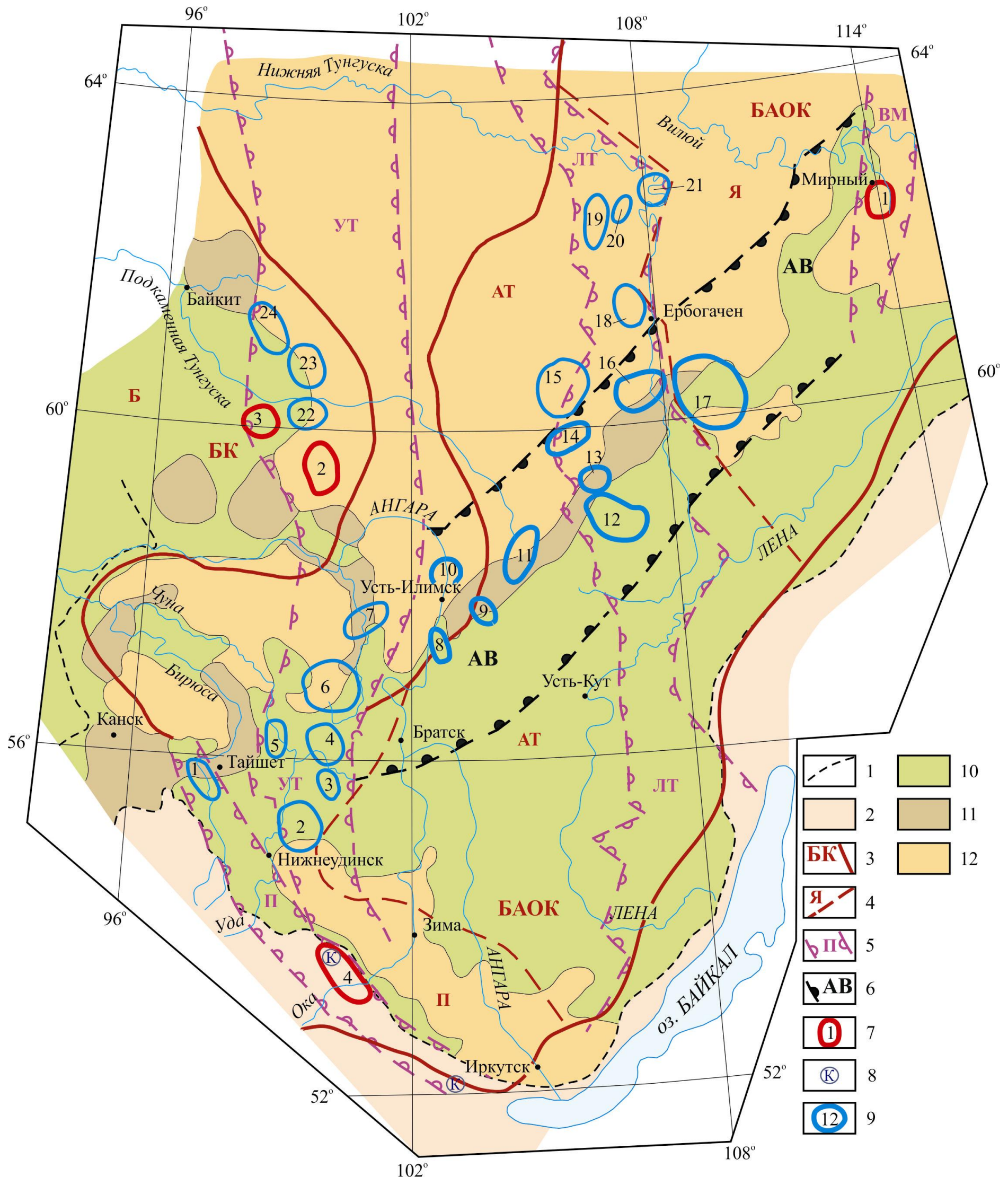


Рис. 18. Расположение алмазоносных минерагенических зон и прогнозируемых площадей на юге Сибирской платформы.

1 - современная граница распространения чехла платформы; 2 - Саяно-Байкальская полициклическая складчатая область; 3 - архейские кратоны Сибирской платформы: Бирюсинско-Ангаро-Оленекский (БАОК), Байкитский (БК); 4 - контуры алмазоносных субпровинций: Якутской (Я), Ангаро-Тунгусской (АТ), Присаянской (П), Байкитской (Б); 5 - алмазоносные минерагенические зоны: Присаянская (П), Удино-Тунгусская (УТ), Лено-Тунгусская (ЛТ), Вилюйско-Мархинская (ВМ); 6 - Ангаро-Вилюйская алмазоносная минерагеническая зона (АВ); 7 - кимберлитовые и лампроитовые поля: 1 - Мирнинское кимберлитовое среднепалеозойское, 2 - Чадобецкое и 3 - ТайгиноТарыдакское кимберлитовые мезозойские, 4 - Ингашинское лампроитовое верхнепротерозойское; 8 - ультраосновные интрузии и карбонатиты Белозиминского комплекса венда; 9 - прогнозируемые перспективные площади, адекватные кимберлитовому или лампроитовому полю: 1 - Ингашетская, 2 - Тангуй-Удинская, 3 - Андочинская, 4 - Чукшинская, 5 - Бирюсинско-Чунская, 6 - Мурская, 7 - Магдонская, 8 - Илимская, 9 - Тубинская, 10 - Тушамская, 11 - Верхнекатангская, 12 - Чангильская, 13 - Икская, 14 - Немуйская, 15 - Алтыбская, 16 - Ереминская, 17 - Верхнечонская, 18 - Верхнекочемская, 19 - Нижнекочемская, 20 - Верхнеапкинская, 21 - Нижнеапкинская, 22 - Тарыдакская, 23 - Шушукская, 24 - Хушмуканская. Интегрированные контуры геологических образований платформенного чехла: 10 - площади, сложенные отложениями рифея - нижнего палеозоя (до силура включительно); 11 - площади распространения образований девона и карбона; 12 - площади, сложенные преимущественно отложениями перми, мезозоя, кайнозоя.

Fig. 18. Locations of diamond-bearing minerogenic zones and forecasted areas in the southern part of the Siberian platform.

1 - current boundary of the platform cover; 2 - Sayan-Baikal polycyclic folded area; 3 - Archean cratons of the Siberian platform (БAOK - Biryusa-Angara-Olenyok, БK- Baykit); 4 - contours of diamond-bearing sub-provinces ( - Yakutian, AT - Angara-Tungusskaya, $\Pi$ - Prisayanskaya, Б - Baykitskaya); 5 - diamond-bearing minerogenic zones (П - Prisayanskaya, УТ - Udino-Tungusskaya, ЛТ - Lena-Tugusskaya, BM Vilujsko-Markhinskaya); 6 - Angara-Vilujskaya diamond-bearing minerogenic zone (AB); 7 - kimberlitic and lamproitic fields: 1 - Mirny kimberlitic field (Middle Paleozoic), 2 - Chadobetskoe and 3 - Tagino-Tarydakskoe kimberlitic fields (Mesozoic), 4 - Ingashinskoe lamproitic field (Upper Proterozoic); 8 - ultrabasic intrusions and carbonatites of the Beloziminsky complex (Vend); 9 - forecasted promising areas that are adequate to a kimberlitic / lamproitic field: 1 - Ingashetskaya, 2 - Tanguy-Udinskaya, 3 - Andochinskaya, 4 - Chukshinskaya, 5 - Biryusa-Chunskaya, 6 - Murskaya, 7 - Magdonskaya, 8 - Ilimskaya, 9 - Tubinskaya, 10 - Tushamskaya, 11 - Verkhnekatangskaya, 12 - Changilskaya, 13 Ikskaya, 14 - Nemuyskaya, 15 - Altybskaya, 16 - Ereminskaya, 17 - Verkhechonskaya, 18 - Verkhekochemskaya, 19 - Nizhnekochemskaya, 20 - Verkheapkinskaya, 21 - Nizhneapkinskaya, 22 - Tarydakskaya, 23 - Shushukskaya, 24 - Khushmukanskaya. Integrated contours of geological formations of the platform cover: 10 - areas composed of the Riphean - Late Paleozoic (to Silurian, inclusively) formations; 11 - areas where the Devonian and Carbon formations are abundant; 12 - areas that are mainly composed of the Permian, Mesozoic and Cenozoic formations.

Сибирской платформе, когда в результате падения серии гигантских астероидных тел произошло Великое мезозойское вымирание, коренным образом изменившее видовой состав биоты планеты [Egorov et al., 2010].

В 2011 г. проведена конференция при значительной поддержке администрации института, посвященная 100-летию со дня рождения чл.-корр. АН СССР М.М. Одинцова - одного из основателей и бессменного (1954-1976 гг.) руководителя Института геологии Восточно-Сибирского филиала АН СССР - Института земной коры СО АН СССР, награжденного орденами Ленина (1963 г., 1971 г.) и орденом Трудового Красного Знамени (1975 г.).

В 2011 г. К.Н. Егоров получил благодарность губернатора Иркутской области. В 2012 г. А.И. Киселев награжден медалью им. М.В. Ломоносова, К.Н. Егоров - медалью к 350-летию г. Иркутска, Л.В. Соловьева, Г.В. Орлова награждены медалью к 75-летию Иркутской области.

\section{3. ПЕРСПЕКТИВЫ}

В ближайшей перспективе (до 2020 г.) лаборатория планирует развивать следующие научные направления, имеющие актуальность и востребованность в на- учном мире: 1) петрология, минералогия и эволюция мантийной литосферы древних кратонов, происхождение алмазов и их коренных и россыпных месторождений; 2) закономерности размещения и условия формирования эндогенных и экзогенных алмазоносных формаций на древних платформах; 3) создание научных основ прогноза и поисков промышленной алмазоносности юго-запада Сибирской платформы на базе разработки моделей лампроитовых, кимберлитовых полей и коренных месторождений алмазов.

Необходимость расширения минерально-сырьевой базы алмазодобывающей промышленности в России требует опережающего научно-методического обеспечения алмазопоисковых работ на новых территориях со сложной геологической обстановкой. Одной из первоочередных задач лаборатории является разработка оригинальных и адаптация существующих прогнознопоисковых технологий к регионам с нетрадиционными коренными источниками алмазов. Для этого необходимо продолжать всестороннее изучение процессов кратонизации литосферы древних платформ, причин и механизмов генерации и последующей эволюции кимберлитовых и лампроитовых расплавов, а также процессов кристаллизации природных алмазов и закономерностей размещения их коренных и россыпных месторождений. 


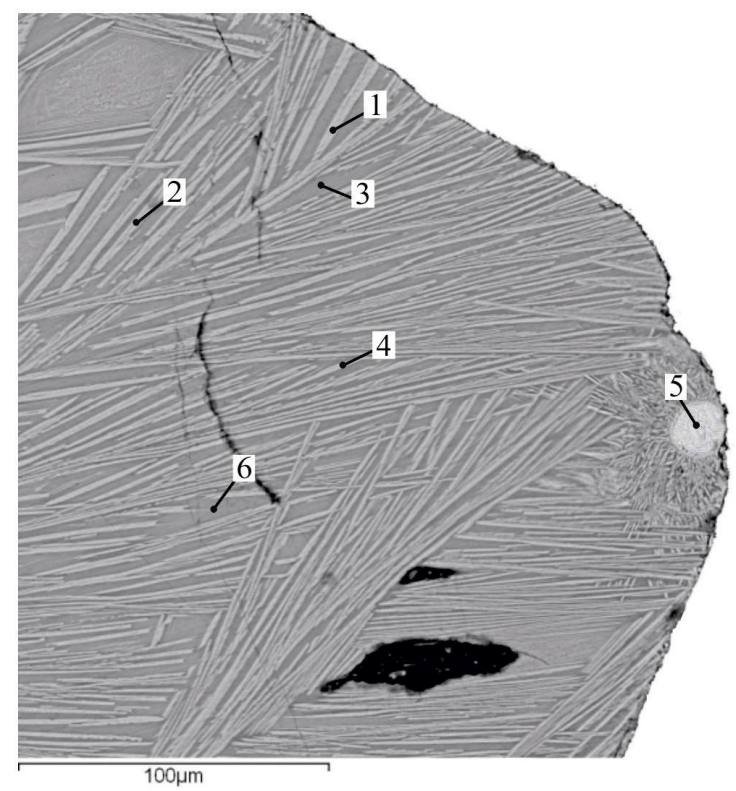

a

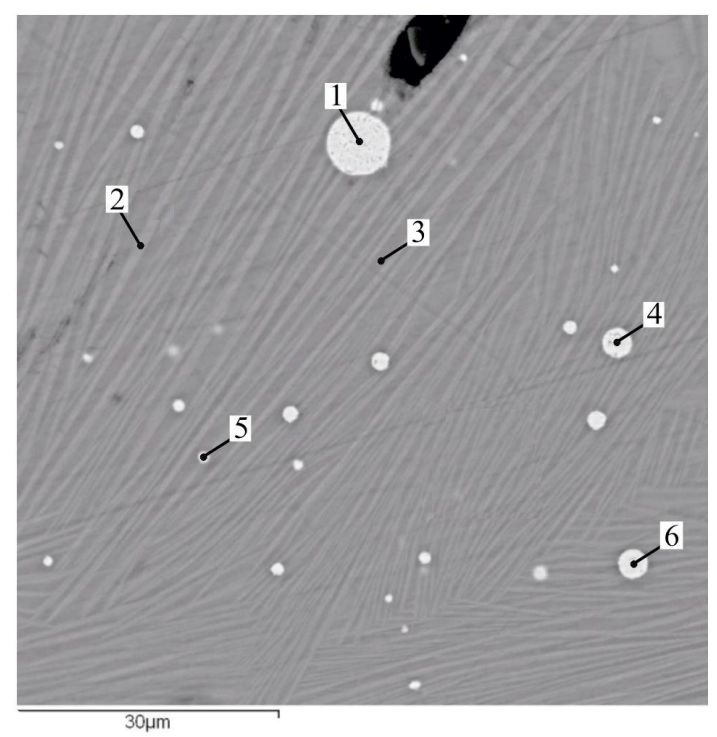

б

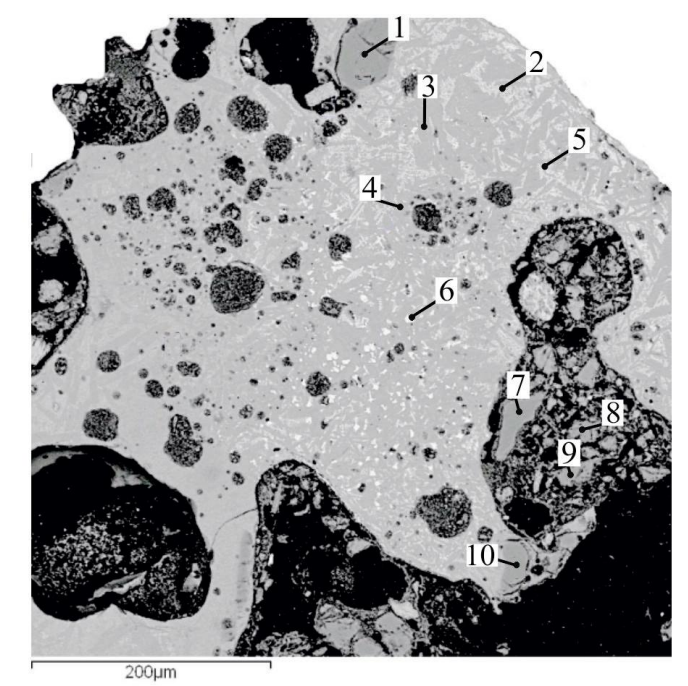

B

Рис. 19. Цифровые изображения обломков витрокластических ( $a$, б) и литовитрокластических $(в)$ разновидностей зювитов в обратно рассеянных электронах.

Fig. 19. Digital photos of fragments of vitroclastic $(a, \sigma)$ and lithovitroclastic ( $($ ) suevites in backscattered electrons. 


\section{ЛИТЕРАТУРA / REFERENCES}

Armbruster T., Lazic B., Gfeller F., Galuskin E.V., Galuskina I.O., Savelyeva V.B., Zadov A.E., Pertsev N.N., Anowski P.D. 2011. Chlorine content and crystal chemistry of dellaite from the birkhin gabbro massif, Eastern Siberia, Russia. Mineralogical Magazine 75 (2), 379-394. http://dx.doi.org/10.1180/minmag.2011.075.2.379.

Danilova Yu.V., Shevchenko S.G., Klyba L.V., Danilov B.S., 2012. Composition of soluble carbonaceous material from rocks of the Arshan tectonic zone (southeastern part of the Eastern Sayan). Geochemistry International 50 (2), 185-192. http://dx.doi.org/10.1134/S001670291202005X.

Dorogokupets P.I., 2010. P-V-T equations of state of MgO and thermodynamics. Physics and Chemistry of Minerals 37 (9), 677-684. http://dx.doi.org/10.1007/s00269-010-0367-2.

Dorogokupets P.I., Sokolova T.S., Danilov B.S., Litasov K.D., 2012. Near-absolute equations of state of diamond, Ag, Al, Au, $\mathrm{Cu}, \mathrm{Mo}, \mathrm{Nb}, \mathrm{Pt}, \mathrm{Ta}$, and W for quasi-hydrostatic conditions. Geodynamics \& Tectonophysics 3 (2), 129-166. http://dx. doi.org/10.5800/GT-2012-3-2-0067.

Egorov K.N., Andryushchenko L.G., Karnaushenko M.G., 2010. The first discovery of impactites from a new astroblem within the South-Western Siberian platform. Doklady Earth Sciences 432 (2), 737-741. http://dx.doi.org/10.1134/S10 28334X1006005X.

Egorov K.N., Kiselev A.I., Menshagin Yu.V., Minayeva Yu.A., 2010. Lamproites and kimberlites of Prisayanye: composition, sources, diamond potential. Doklady Earth Sciences 435 (2), 1670-1675. http://dx.doi.org/10.1134/S1028334X101202 51.

Egorov K.N., Kiselev A.I., Yarmoluk V.V., Nikiforova A.V., 2011. Composition and sources of magmatism of the Vilyui Middle Paleozoic rift area and the problem of combination of its basic rock and kimberlite derivatives. Doklady Earth Sciences 436 (1), 76-82. http://dx.doi.org/10.1134/S1028334X11010144.

Egorov K.N., Melnikov A.I., 2013. Structural-compositional evolution of the kimberlite bodies system from the Udachnaya pipe. Rudy i metally 1, 53-59 (in Russian) [Егоров К.Н., Мельников А.И. Структурно-вещественная эволюция системы кимберлитовых тел трубки «Удачная» // Руды и металлы. 2013. № 1. С. 53-59].

Egorov K.N., Solovyeva L.V., Koshkarev D.A., 2012. Rare element composition of pyropes from lamproites and ancient dispersion halo of the South-Western Siberian platform. Doklady Earth Sciences 443 (2), 496-501. http://dx.doi.org/10. 1134/S1028334X12040125.

Galuskin E.V., Gfeller F., Savelyeva V.B., Armbruster T., Lazic B., Galuskina I.O., Többens D.M., Zadov A.E., Dzierzanowski P., Pertsev N.N., Gazeev V.M., 2012. Pavlovskyite $\mathrm{Ca}_{8}\left(\mathrm{SiO}_{4}\right)_{2}\left(\mathrm{Si}_{3} \mathrm{O}_{10}\right)$ : A new mineral of altered silicatecarbonate xenoliths from the two Russian type localities, Birkhin massif, Baikal Lake area and Upper Chegem caldera, North Caucasus. American Mineralogist 97 (4), 503-512. http://dx.doi.org/10.2138/am.2012.3970.

Gfeller F., Armbruster T., Galushkin E.V., Galushkina I.O., Lazic B., Savelyeva V.B., Zadov A.E., Dzierżanovski P., Gazeev V.M., 2013. Crystal chemistry and hydrogen bonding of rustumite $\mathrm{Ca}_{10}\left(\mathrm{Si}_{2} \mathrm{O}_{7}\right)_{2}\left(\mathrm{SiO}_{4}\right)(\mathrm{OH})_{2} \mathrm{Cl}_{2}$ with variable $\mathrm{OH}, \mathrm{Cl}, \mathrm{F}$. American Mineralogist 98 (2-3), 493-500. http://dx.doi.org/10.2138/am.2013.4257.

Grakhanov S.A., Smelov A.P., Egorov K.N., Golubev Yu.K., 2010. Sedimentary-volcanogenic nature of coarse-grained sediments of the Carnian stage of the North-Eastern Siberian platform - a new type of the primary diamond sources. Otechestvennaya geologia 6, 3-13 (in Russian) [Граханов С.А., Смелов А.П., Егоров К.Н., Голубев Ю.К. Осадочновулканогенная природа грубообломочных отложений карнийского яруса северо-восточного обрамления Сибирской платформы - нового типа коренных источников алмазов // Отечественная геология. 2010. № 6. С. 3-13].

Hultquist G., Szakálos P., Graham M.J., Belonoshko A.B., Sproule G.I., Gråsjö L., Dorogokupets P., Danilov B., Astrup T., Wikmark G., Chuah G.-K., Eriksson J.-C., Rosengren A., 2009. Water Corrodes Copper. Catalysis Letters 132 (3-4), 311-316. http://dx.doi.org/10.1007/s10562-009-0113-X.

Ivanova L.A., Marchuk M.V., Medvedev B.Y., 2010. Experimental investigation of the fayalite forming in the fluid $\mathrm{H}_{2} \mathrm{O}-\mathrm{H}_{2^{-}}$ $\mathrm{NH}_{3}$. Zapiski RMO 139 (3), 115-121 (in Russian) [Иванова Л.А., Марчук М.В., Медведев В.Я. Экспериментальное исследование образования фаялита во флюиде $\mathrm{H}_{2} \mathrm{O}-\mathrm{H}_{2}-\mathrm{NH}_{3}$ // Записки РМО. 2010. Т. 139. № 3. С. 115-121].

Kiselev A.I., Ernst R.E., Yarmolyuk V.V., Egorov K.N. 2012. Radiated rifts and dyke swarms of the middle Paleozoic Yakutsk plume of eastern Siberian craton. Journal of Asian Earth Sciences 45 (2), 1-16. http://dx.doi.org/10.1016/j.jseaes. 2011.09.004.

Kiselev A.I., Yarmoluk V.V., Kolodeznikov I.I., 2010. Comparative characteristics of the Middle Paleozoic and Late Riphean plume magmatism of the Siberian platform (based on the isotopic-geochemical results of the Sette-Daban basic rocks study). Doklady Earth Sciences 430 (1), 70-77. http://dx.doi.org/10.1134/S1028334X10010010.

Kopylova M.G., Kostrovitsky S.I., Egorov K.N. 2013. Salts in southern Yakutian kimberlites and the problem of primary alkali kimberlite melts. Earth Science Reviews 119, 1-16. http://dx.doi.org/10.1016/j.earscirev.2013.01.007.

Koshkarev D.A., Egorov K.N., Karpenko M.A., Makovchuk I.V., 2010. The main parameters of the diamond potential of geologo-technological types of kimberlite ores from the largest diamond deposit of Yakutia (Yubileinaya pipe). Rudy i metally 4, 27-35 (in Russian) [Кошкарев Д.А., Егоров К.Н., Карпенко М.А., Маковчук И.В. Основные параметры алмазоносности геолого-технологических типов кимберлитовых руд крупнейшего месторождения алмазов Якутии (трубка Юбилейная) // Руды и металлы. 2010. № 4. С. 27-35]. 
Koshkarev D.A., Egorov K.N., Slagoda Ye.A., Denisenko Ye.P., 2010. Lower Carboniferous pyrope-bearing sediments of the Angara-Uda interfluve and problem of the primary diamond potential within the Southern Siberian platform. Regionalnaya geologia i metallogenia 41, 82-92 (in Russian) [Кошкарев Д.А., Егоров К.Н., Слагода Е.А., Денисенко Е.П. Нижнекарбоновые пиропсодержащие отложения Ангаро-Удинского междуречья и проблема коренной алмазоносности юга Сибирской платформы // Региональная геология и металлогения. 2010. № 41. С. 82-92].

Lacis B., Armbruster T., Savelyeva V.B., Zadov A.E., Pertsev N.N., Dzierżanovski P., 2011. Galuskinite, $\mathrm{Ca}_{7}\left(\mathrm{SiO}_{4}\right)_{3}\left(\mathrm{CO}_{3}\right)$, a new skarn mineral from the Birkhin gabbro massif, Eastern Siberia, Russia. Mineralogical Magazine 75 (5), 2631-2648. http://dx.doi.org/10.1180/minmag.2011.075.5.2631.

Letnikov F.A., 2009. Autonomous fluid systems of the continental crust. Doklady Earth Sciences 427 (2), $947-949$. http://dx.doi.org/10.1134/S1028334X09060130.

Letnikov F.A., Danilov B.S., Dorogokupets P.I., 2011. Energy parameters of deep fluid systems. Doklady Earth Sciences 437 (2), 548-551. http://dx.doi.org/ 10.1134/S1028334X11040210.

Letnikov F.A., Ivanova L.A., Medvedev V.Ya., Kuznetsov K.E., 2012. Experimental study of the self-organization process of a fluidized granite melt under decompression. Doklady Earth Sciences 443 (2), 506-508. http://dx.doi.org/10.1134/ S1028334X12040150.

Letnikov F.A., Kotov A.B., Degtyarev K.E., Sal'nikova E.B., Levchenkov O.A., Shershakova M.M., Shershakov A.V., Rizvanova N.G., Makeev A.F., Tolkachev M.D., 2009. Silurian granites of northern Kazakhstan: U-Pb age and tectonic position. Stratigraphy and Geological Correlation 17 (3), 275-282. http://dx.doi.org/10.1134/S0869593809030034.

Letnikov F.A., Letnikova A.F., Danilov B.S., 2013. Relationship between the Heat and Chemical Energies of Components in Deep Fluid Systems. Doklady Earth Sciences 453 (2), 1234-1236. http://dx.doi.org/10.1134/S1028334X13120106.

Letnikov F.A., Levin A.V., 2013. Geochemical correlation between dykes of topaz granites and elvans (Kokchetav block, Northern Kazakhstan). Doklady Earth Sciences 448 (1), 58-60. http://dx.doi.org/10.1134/S1028334X13010054.

Letnikov F.A., Zayachkovskii A.A., Letnikova A.F., 2010. On the geochemical specialization of deep-seated high-carbonaceous systems. Doklady Earth Sciences 433 (1), 962-965. http://dx.doi.org/10.1134/S1028334X10070251.

Levin A.V., Letnikova A.F., 2010. Tourmaline granite of the Kumdykol graphite-diamond deposit. Doklady Earth Sciences 435 (2), 1637-1640. http://dx.doi.org/10.1134/S1028334X10120184.

Litasov K.D., Dorogokupets P.I., Ohtani E., Fei Y., Shatskiy A., Sharygin I.S., Gavryushkin P.N., Rashchenko S.V., Seryotkin Y.V., Higo Y., Funakoshi K., Chanyshev A.D., Lobanov S.S., 2013. Thermal equation of state and thermodynamic properties of molybdenum at high pressures. Journal of Applied Physics 113, 093507. http://dx.doi.org/10.1063/1.4794127.

Litasov K.D., Gavryushkin P.N., Dorogokupets P.I., Sharygin I.S., Shatskiy A., Fei Y., Rashchenko S.V., Seryotkin Y.V., Higo Y., Funakoshi K., Ohtani E., 2013. Thermal equation of state to $33.5 \mathrm{GPa}$ and $1673 \mathrm{~K}$ and thermodynamic properties of tungsten. Journal of Applied Physics 113, 133505. http://dx.doi.org/10.1063/1.4799018.

Litasov K.D., Sharygin I.S., Shatskii A., Gavryushkin P.N., Dorogokupets P.I., Sokolova T.S., Ohtani E., Dymshits A.M., Alifirova T.A. 2013. P-V-T Equations of state for iron carbides $\mathrm{Fe}_{3} \mathrm{C}$ and $\mathrm{Fe}_{7} \mathrm{C}_{3}$ and their relationships under the conditions of the Earth's mantle and core. Doklady Earth Sciences 453 (2), 1269-1273. http://dx.doi.org/10.1134/S1028334X 13120192.

Litasov, K.D., Sharygin I.S., Dorogokupets P.I., Shatskiy A., P.N. Gavryushkin P.N., Sokolova T.S., Ohtani E., Li J., Funakoshi K., 2013. Thermal equation of state and thermodynamic properties of iron carbide $\mathrm{Fe}_{3} \mathrm{C}$ to $31 \mathrm{GPa}$ and $1473 \mathrm{~K}$. Journal Geophysical Research: Solid Earth 118, 5274-5284. http://dx.doi.org/10.1002/2013JB010270.

Litasov K.D., Shatskiy A., Gavryushkin P.N., Sharygin I.S., Dorogokupets P.I., Dymshits A.M., Ohtani E., Higo Y., Funakoshi K., 2013. P-V-T equation of state of siderite to 33 GPa and 1673 K. Physics of the Earth and Planetary Interiors 224, 8387. http://dx.doi.org/10.1016/j.pepi.2013.07.011.

Sapozhnikov A.N., Kaneva E.V., Cherepanov D.I., Suvorova L.F., Levitsky V.I., Ivanova L.A., Reznitsky L.Z., 2012. Vladimirivanovite, $\mathrm{Na}_{6} \mathrm{Ca}_{2}\left[\mathrm{Al}_{6} \mathrm{Si}_{6} \mathrm{O}_{24}\right]\left(\mathrm{SO}_{4}, \mathrm{~S}_{3}, \mathrm{~S}_{2}, \mathrm{Cl}\right)_{2} \cdot \mathrm{H}_{2} \mathrm{O}$, a new mineral of sodalite group. Geology of Ore Deposits 54 (7), 557-564. http://dx.doi.org/10.1134/S1075701512070070.

Savel'eva V.B., Bazarova E.P., 2012. The Early Proterozoic Primorskii complex of rapakivi granites (western Cisbaikalia): Geochemistry, crystallization conditions, and ore potential. Russian Geology and Geophysics 53 (2), 147-168. http://dx. doi.org/10.1016/j.rgg.2011.12.012.

Savel'eva V.B., Bazarova E.P., Karmanov N.S., 2011. Accessory minerals from the Primorsky rapakivi granite complex, West Baikal Region. Geology of Ore Deposits 53 (8), 708-722. http://dx.doi.org/10.1134/S1075701511080149.

Savel'eva V.B., Karmanov N.S., 2010. Quartz-albite-microcline metasomatic rocks in the main Sayan faault zone: evolution of metasomatism and composition of accessory minerals. Geology of Ore Deposits 52 (4), 302-321. http://dx.doi.org/ 10.1134/S1075701510040057.

Savel'eva V.B., Presnyakov S.L., Lepekhina E.N., Larionov A.N., Bazarova E.P., 2012. Principle stages of granite and pegmatite formation in the southeastern part of the Main Sayan Fault. Doklady Earth Sciences 442 (1), 49-55. http://10.1134/ S1028334X12010291.

Shumilova T.G., Danilova Yu.V., 2009. New genetic type of graphite in connection with travertines. Doklady Earth Sciences 428 (1), 1171-1173. http://dx.doi.org/10.1134/S1028334X09070290. 
Shumilova T.G., Danilova Yu.V., Gorbunov M.V., Isaenko S.I., 2011. Natural monocrystalline $\alpha$-carbyne. Doklady Earth Sciences 436 (1), 152-154. http://dx.doi.org/10.1134/S1028334X11010314.

Sokolova T.S., Dorogokupets P.I., Litasov K.D., 2013. Self-consistent pressure scales based on the equations of state for ruby, diamond, MgO, B2-NaCl, as well as $\mathrm{Au}, \mathrm{Pt}$, and other metals to 4 Mbar and $3000 \mathrm{~K}$. Russian Geology and Geophysics 54 (2), 181-199. http://dx.doi.org/10.1016/j.rgg.2013.01.005.

Solov'eva L.V., Yasnygina T.A., Egorov K.N. 2012. Metasomatic parageneses in deep-seated xenoliths from pipes Udachnaya and Komsomol'skaya-Magnitnaya as indicators of fluid transfer through the mantle lithosphere of the Siberian craton. Russian Geology and Geophysics 53 (12), 1304-1323. http://dx.doi.org/10.1016/j.rgg.2012.10.004.

Solovyeva L.V., Yasnygina T.A., Koroluk V.N., Egorov K.N., 2010. Geochemical evolution of deep fluids in the mantle lithosphere of the Siberan craton during the Middle Paleozoic kimberlite cycle. Doklady Earth Sciences 434 (2), 1330-1336. http://dx.doi.org/10.1134/S1028334X10100090.

Turkina O.M., Letnikov F.A., Levin A.V., 2011. Mesoproterozoic granitoids of the Kokchetav microcontinent basement. Doklady Earth Sciences 436 (2), 176-180. http://dx.doi.org/10.1134/S1028334X11020103.

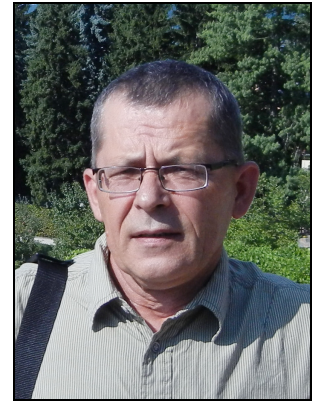

Дорогокупец Петр Иванович, докт. геол.-мин. наук, зав. лабораторией петрологии, геохимии и рудогенеза

Институт земной коры СО РАН

664033, Иркутск, ул. Лермонтова, 128, Россия

e-mail: dor@crust.irk.ru

Dorogokupets, Peter I., Doctor of Geology and Mineralogy, Head of Laboratory of Petrology, Geochemistry and Ore Genesis

Institute of the Earth's Crust, Siberian Branch of RAS

128 Lermontov street, Irkutsk 664033, Russia

e-mail: dor@crust.irk.ru

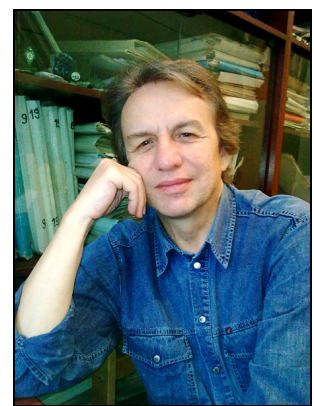

Егоров Константин Николаевич, канд. геол.-мин. наук, зав. лабораторией геологии и магматизма древних платформ Институт земной коры СО РАН

664033, Иркутск, ул. Лермонтова, 128, Россия

e-mail: egorov@crust.irk.ru

Egorov, Konstantin N., Candidate of Geology and Mineralogy, Head of Ancient Platforms Geology \& Magmatism Laboratory, Institute of the Earth's Crust, Siberian Branch of RAS

128 Lermontov street, Irkutsk 664033, Russia

e-mail: egorov@crust.irk.ru 